THE RING 31, 2 (2009) DOI 10.2478/v10050-008-0051-9

\title{
DYNAMICS OF AUTUMN MIGRATION OF THE Acrocephalus WARBLERS THROUGH THE POLISH BALTIC COAST
}

\author{
Anna Kozłowska, Katarzyna Stępniewska, \\ Krzysztof Stępniewski and Przemysław Busse
}

\begin{abstract}
Kozłowska A., Stępniewska K., Stępniewski K., Busse P. 2009. Dynamics of autumn migration of the Acrocephalus warblers through the Polish Baltic coast. Ring 31, 2: 15-43.

We analyse in our paper the autumn migration of five warblers: i.e. the Reed Warbler (Acrocephalus scirpaceus), Sedge Warbler (A. schoenobaenus), Marsh Warbler (A. palustris), Great Reed Warbler (A. arundinaceus) and Aquatic Warbler (A. paludicola), through the Polish Baltic coast. Data were collected in 1962-2005 at two stations: Bukowo-Kopań and Mierzeja Wiślana, as well as (for a comparison) at the Drużno station in 1990-2002 and 2003-2005. The most numerous species caught at all the stations was the Reed Warbler, whereas the Aquatic Warbler was caught only sporadically. Long-term number dynamics from Bukowo-Kopań and Mierzeja Wiślana showed considerable fluctuations for the first four species, which could have been influenced by weather or habitat changes, or they could have reflected long-term population cycles. Strong correlations between the numbers of species preferring reeds might indicate habitat basis of the fluctuations. Seasonal migration dynamics were also similar, with the peak of migration in mid-August. However, the dynamics from Drużno suggested that the real peak of migration occurred earlier. Median dates of the Reed Warbler migration at Bukowo-Kopań showed marked fluctuations, whereas at Mierzeja Wiślana they were delayed significantly; these changes were probably connected with climate changes.
\end{abstract}

A. Kozłowska, K. Stępniewska, K. Stępniewski, P. Busse, Bird Migration Research Station, University of Gdańsk, Przebendowo, PL-84-210 Choczewo, Poland, E-mail: busse@univ.gda.pl Publication appointed to the SE European Bird Migration Network papers

Key words: Acrocephalus, autumn migration, migration dynamics, Baltic coast

\section{INTRODUCTION}

Five breeding species: the Great Reed Warbler (Acrocephalus arundinaceus), Reed Warbler (A. scirpaceus), Marsh Warbler (A. palustris), Sedge Warbler (A. schoenobaenus) and the AquaticWarbler (A. paludicola) represent the genus Acrocephalus in Poland. 
The first four species are widely distributed over the whole lowland of the country, being quite numerous in the river valleys, near lakes and fishponds, whereas the Aquatic Warbler, a globally threatened species, can be found only at a few sites in Poland. Birds of this genus mostly inhabit open wetlands, especially reedbeds near water, as well as sedge marshes with clumps of reeds and willows; the only exception is the Marsh Warbler, which inhabits willow bushes with abundant herbaceous vegetation, edges of damp forests and even farmland and suburban parks (Tomiałojć and Stawarczyk 2003).

All the Acrocephalus warblers are long-distance migrants. Their winter quarters are situated in Africa south from Sahara, from Senegal to Ethiopia and south to the Republic of South Africa (Cramp 1992). In spring they arrive in Poland from the middle of April till the beginning of June. Autumn migration begins as early as in July, overlapping with the breeding season; the last birds leave in September (Great Reed and Marsh Warblers) or October (other species; Cramp 1992, Tomiałojć and Stawarczyk 2003).

In the literature there is a lack of detailed description of the Acrocephalus warblers' migration through the Polish Baltic coast. In several summary papers, migration dynamics of some species are given, but without any comprehensive comparisons or analyses (Busse and Halastra 1981, Busse 1994). The only more thorough paper deals with the migration of the Reed Warbler, but it includes only the data from Mierzeja Wiślana and Drużno (Szostakowski 1989). Therefore, the aim of this paper is to analyse the autumn migration of Acrocephalus warblers passing the Polish Baltic coast, with regard to seasonal migration dynamics as well as to long-term number dynamics.

\section{MATERIAL AND METHODS}

The ringing data were collected during the autumn migration period at the ringing stations: Mierzeja Wiślana and Bukowo-Kopań in 1962-2005, as well as at the Drużno ringing station in 1990-2002 and 2003-2005. The total numbers of the Acrocephalus warblers caught at individual stations in all the years are presented in Tables 1-3. The tables and further analyses do not include a single case of catching a vagrant species: the Paddyfield Warbler (Acrocephalus agricola), which was caught on 23 August 2005 at the Bukowo-Kopań Bagno ringing station, ca $900 \mathrm{~m}$ east from Bukowo-Kopań.

\section{Study area}

The Mierzeja Wiślana ringing station $\left(51^{\circ} 22^{\prime} \mathrm{N}, 19^{\circ} 24^{\prime} \mathrm{E}\right)$, “Mierzeja” in short, is situated on the Vistula Spit, ca $100 \mathrm{~m}$ from the NW coast of the Vistula Lagoon, which is a shallow (2.6 m deep on average) and eutrophic lagoon with slightly saline water and extensive reedbeds along the banks. Since 1961 the ringing site has been moved several times due to habitat changes, but the distance from the previous location was always less than $500 \mathrm{~m}$, and the nets were placed in the same, continuous belt of reedbeds (Busse and Kania 1970, Remisiewicz and Baumanis 1996). Because of these reedbeds, the Mierzeja station is particularly suitable for catching the Acrocephalus warblers. Besides the reedbeds, the vegetation of Mierzeja consists of a mixed forest 
Table 1

Periods of work at the Bukowo-Kopań station and numbers of caught birds

\begin{tabular}{|c|c|c|c|c|c|c|}
\hline Year & Period of work & ACR.IRP & ACR.ENO & ACR.UST & ACR.ARU & ACR.OLA \\
\hline 1962 & 9 Sep. - 15 Oct. & 19 & 0 & 0 & 0 & 0 \\
\hline 1963 & 6 Sep. -15 Oct. & 62 & 3 & 0 & 0 & 0 \\
\hline 1964 & 6 Sep. -15 Oct. & 20 & 2 & 0 & 0 & 0 \\
\hline 1965 & 7 Sep. - 15 Oct. & 60 & 2 & 0 & 0 & 0 \\
\hline 1966 & 6 Sep. -15 Oct. & 40 & 0 & 1 & 0 & 0 \\
\hline 1967 & 17 Aug. - 25 Oct. & 125 & 8 & 1 & 6 & 0 \\
\hline 1968 & 16 Aug. - 23 Oct. & 71 & 1 & 0 & 0 & 0 \\
\hline 1969 & 17 Aug. -25 Oct. & 66 & 2 & 0 & 2 & 0 \\
\hline 1970 & 6 Sep. -10 Oct. & 10 & 0 & 0 & 0 & 0 \\
\hline 1971 & 17 Aug. - 22 Oct. & 450 & 23 & 14 & 15 & 0 \\
\hline 1972 & 14 Aug. - 27 Oct. & 332 & 14 & 7 & 10 & 0 \\
\hline 1973 & 13 Aug. - 27 Oct. & 194 & 4 & 19 & 1 & 0 \\
\hline 1974 & 14 Aug. - 27 Oct. & 199 & 4 & 2 & 0 & 0 \\
\hline 1975 & 14 Aug. -27 Oct. & 425 & 7 & 3 & 12 & 0 \\
\hline 1976 & 14 Aug. - 1 Nov. & 395 & 14 & 6 & 5 & 0 \\
\hline 1977 & 16 Aug. - 1 Oct. & 369 & 9 & 2 & 1 & 0 \\
\hline 1978 & 13 Aug. -3 Nov. & 230 & 5 & 2 & 7 & 1 \\
\hline 1979 & 16 Aug. - 1 Nov. & 105 & 6 & 0 & 0 & 0 \\
\hline 1980 & 14 Aug. - 1 Nov. & 223 & 6 & 13 & 1 & 0 \\
\hline 1981 & 13 Aug. - 1 Nov. & 220 & 17 & 12 & 3 & 0 \\
\hline 1982 & 13 Aug. - 1 Nov. & 260 & 8 & 14 & 5 & 0 \\
\hline 1983 & 13 Aug. - 1 Nov. & 54 & 5 & 14 & 0 & 0 \\
\hline 1984 & 13 Aug. - 1 Nov. & 13 & 0 & 3 & 0 & 0 \\
\hline 1985 & 14 Aug. - 1 Nov. & 9 & 0 & 7 & 0 & 0 \\
\hline 1986 & 14 Aug. - 1 Nov. & 11 & 0 & 0 & 0 & 0 \\
\hline 1987 & 14 Aug. - 1 Nov. & 7 & 0 & 0 & 0 & 0 \\
\hline 1988 & 13 Aug. - 1 Nov. & 30 & 0 & 1 & 1 & 0 \\
\hline 1989 & 14 Aug. - 1 Nov. & 16 & 0 & 1 & 1 & 0 \\
\hline 1990 & 13 Aug. - 1 Nov. & 35 & 0 & 13 & 0 & 0 \\
\hline 1991 & 13 Aug. - 1 Nov. & 11 & 1 & 9 & 0 & 0 \\
\hline 1992 & 14 Aug. - 1 Nov. & 16 & 1 & 7 & 0 & 0 \\
\hline 1993 & 13 Aug. - 1 Nov. & 19 & 5 & 5 & 0 & 0 \\
\hline 1994 & 13 Aug. - 2 Nov. & 23 & 3 & 11 & 0 & 0 \\
\hline 1995 & 14 Aug. - 2 Nov. & 24 & 2 & 8 & 0 & 0 \\
\hline 1996 & 14 Aug. - 4 Nov. & 145 & 8 & 14 & 1 & 0 \\
\hline 1997 & 14 Aug. - 3 Nov. & 88 & 5 & 55 & 2 & 0 \\
\hline 1998 & 13 Aug. - 2 Nov. & 87 & 4 & 36 & 0 & 0 \\
\hline 1999 & 12 Aug. - 6 Nov. & 216 & 2 & 35 & 3 & 0 \\
\hline 2000 & 13 Aug. - 11 Nov. & 162 & 7 & 76 & 0 & 0 \\
\hline 2001 & 12 Aug. - 11 Nov. & 220 & 14 & 47 & 4 & 0 \\
\hline 2002 & 13 Aug. - 16 Nov. & 465 & 56 & 107 & 29 & 1 \\
\hline 2003 & 13 Aug. - 16 Nov. & 268 & 29 & 38 & 7 & 0 \\
\hline 2004 & 13 Aug. - 11 Nov. & 417 & 31 & 48 & 19 & 0 \\
\hline 2005 & 13 Aug. - 17 Nov. & 130 & 6 & 71 & 0 & 0 \\
\hline Total & & 6341 & 314 & 702 & 135 & 2 \\
\hline
\end{tabular}

Species codes: ACR.IRP - Reed Warbler, ACR.ENO - Sedge Warbler, ACR.UST - Marsh Warbler, ACR.ARU - Great Reed Warbler, ACR.OLA - Aquatic Warbler 
Table 2

Periods of work at the Mierzeja Wiślana station and numbers of caught birds

\begin{tabular}{|c|c|c|c|c|c|c|}
\hline Year & Period of work & ACR.IRP & ACR.ENO & ACR.UST & ACR.ARU & ACR.OLA \\
\hline 1962 & 20 Aug. - 30 Sep. & 82 & 2 & 2 & 19 & 0 \\
\hline 1963 & 17 Aug. - 30 Oct. & 416 & 23 & 5 & 48 & 1 \\
\hline 1964 & 15 Aug. - 25 Oct. & 409 & 49 & 0 & 30 & 3 \\
\hline 1965 & 17 Aug. - 25 Oct. & 104 & 29 & 0 & 23 & 0 \\
\hline 1966 & 17 Aug. - 25 Oct. & 566 & 73 & 0 & 46 & 0 \\
\hline 1967 & 17 Aug. - 26 Oct. & 215 & 8 & 0 & 10 & 0 \\
\hline 1968 & 17 Aug. - 25 Oct. & 471 & 47 & 4 & 23 & 1 \\
\hline 1969 & 17 Aug - 25 Oct. & 161 & 8 & 1 & 3 & 0 \\
\hline 1970 & 15 Aug. - 14 Nov. & 139 & 20 & 0 & 8 & 0 \\
\hline 1971 & 17 Aug. - 14 Nov. & 459 & 30 & 1 & 33 & 1 \\
\hline 1972 & 14 Aug. - 14 Nov. & 442 & 31 & 0 & 14 & 0 \\
\hline 1973 & 14 Aug. - 18 Nov. & 590 & 33 & 0 & 0 & 0 \\
\hline 1974 & 14 Aug. - 1 Nov. & 460 & 20 & 7 & 0 & 0 \\
\hline 1975 & 15 Aug. - 2 Nov. & 943 & 57 & 3 & 8 & 0 \\
\hline 1976 & 14 Aug. - 1 Nov. & 550 & 39 & 4 & 20 & 0 \\
\hline 1977 & 16 Aug. - 2 Nov. & 192 & 9 & 0 & 3 & 0 \\
\hline 1978 & 13 Aug. - 1 Nov. & 700 & 39 & 8 & 18 & 0 \\
\hline 1979 & 13 Aug. - 1 Nov. & 291 & 12 & 3 & 3 & 0 \\
\hline 1980 & 13 Aug. - 1 Nov. & 520 & 30 & 4 & 19 & 0 \\
\hline 1981 & 14 Aug. - 1 Nov. & 203 & 46 & 1 & 16 & 0 \\
\hline 1982 & 14 Aug. - 1 Nov. & 713 & 75 & 2 & 70 & 0 \\
\hline 1983 & 13 Aug. - 1 Nov. & 608 & 118 & 9 & 35 & 1 \\
\hline 1984 & 12 Aug. - 1 Nov. & 333 & 89 & 2 & 6 & 2 \\
\hline 1985 & 13 Aug. - 1 Nov. & 468 & 27 & 4 & 16 & 0 \\
\hline 1986 & 14 Aug. - 1 Nov. & 389 & 39 & 10 & 33 & 0 \\
\hline 1987 & 9 Aug. - 1 Nov. & 423 & 74 & 26 & 33 & 0 \\
\hline 1988 & 14 Aug. - 1 Nov. & 464 & 61 & 19 & 35 & 0 \\
\hline 1989 & 13 Aug. - 1 Nov. & 258 & 53 & 5 & 4 & 0 \\
\hline 1990 & 13 Aug. - 1 Nov. & 235 & 33 & 1 & 6 & 0 \\
\hline 1991 & 13 Aug. - 1 Nov. & 535 & 41 & 18 & 15 & 1 \\
\hline 1992 & 13 Aug. - 1 Nov. & 446 & 47 & 4 & 19 & 0 \\
\hline 1993 & 13 Aug. - 1 Nov. & 132 & 17 & 3 & 1 & 0 \\
\hline 1994 & 9 Aug. - 1 Nov. & 432 & 42 & 9 & 24 & 0 \\
\hline 1995 & 29 Jul. - 2 Nov. & 594 & 67 & 13 & 18 & 0 \\
\hline 1996 & 28 Jul. - 3 Nov. & 242 & 36 & 16 & 12 & 0 \\
\hline 1997 & 13 Aug. - 1 Nov. & 275 & 27 & 7 & 4 & 0 \\
\hline 1998 & 13 Aug. - 1 Nov. & 438 & 28 & 7 & 20 & 0 \\
\hline 1999 & 12 Aug. - 13 Nov. & 390 & 30 & 13 & 20 & 0 \\
\hline 2000 & 13 Aug. - 1 Nov. & 580 & 90 & 15 & 21 & 0 \\
\hline 2001 & 12 Aug. - 1 Nov. & 1042 & 111 & 11 & 60 & 0 \\
\hline 2002 & 13 Aug. - 2 Nov. & 1134 & 149 & 24 & 44 & 0 \\
\hline 2003 & 13 Aug. - 1 Nov. & 422 & 73 & 9 & 21 & 1 \\
\hline 2004 & 12 Aug. - 1 Nov. & 1125 & 70 & 7 & 56 & 0 \\
\hline 2005 & 14 Aug. - 1 Nov. & 262 & 42 & 1 & 16 & 1 \\
\hline Total & & 19853 & 2044 & 278 & 933 & 12 \\
\hline
\end{tabular}

Species codes as in Table 1 
Table 3

Periods of work at the Drużno station and numbers of caught birds

\begin{tabular}{|r|c|c|c|c|c|}
\hline Years & Period of work & ACR.IRP & ACR.ENO & ACR.UST & ACR.ARU \\
\hline 1990 & 2 Aug. - 29 Aug. & 329 & 225 & 40 & 12 \\
\hline 1991 & 3 Aug. - 25 Aug. & 300 & 127 & 44 & 8 \\
\hline 1992 & 3 Aug. - 29 Aug. & 400 & 262 & 83 & 28 \\
\hline 1993 & 2 Aug. - 15 Aug. & 127 & 135 & 12 & 7 \\
\hline 1994 & 4 Aug. - 26 Aug. & 209 & 184 & 59 & 10 \\
\hline 1995 & 3 Aug. - 30 Aug. & 269 & 385 & 89 & 28 \\
\hline 1996 & 2 Aug. - 30 Aug. & 518 & 590 & 245 & 29 \\
\hline 1997 & 3 Aug. - 30 Aug. & 329 & 246 & 93 & 30 \\
\hline 1998 & 3 Aug. - 30 Aug. & 621 & 367 & 128 & 32 \\
\hline 1999 & 29 Jul. - 31 Aug. & 418 & 307 & 159 & 28 \\
\hline 2000 & 24 Jul. - 10 Sep. & 713 & 665 & 257 & 45 \\
\hline 2001 & 25 Aug. - 5 Sep. & 455 & 320 & 89 & 58 \\
\hline 2002 & 1 Aug. - 5 Sep. & 483 & 585 & 151 & 35 \\
\hline 2004 & 27 Jul. - 5 Sep. & 618 & 561 & 123 & 47 \\
\hline 2005 & 25 Aug. - 4 Sep. & 489 & 556 & 223 & 61 \\
\hline Total & & $\mathbf{6 2 7 8}$ & $\mathbf{5 5 1 5}$ & $\mathbf{1 7 9 5}$ & $\mathbf{4 5 8}$ \\
\hline
\end{tabular}

Species codes as in Table 1

a mixed forest with abundant understory, composed of the Black Alder (Alnus glutinosa), Scots Pine (Pinus sylvestris), European Beech (Fagus sylvatica), Norway Spruce (Picea abies) and Pedunculate Oak (Quercus robur).

The second station, Bukowo, which operated in 1961-1984, was situated on a narrow spit separating Lake Bukowo from the Baltic Sea. Since 1982 ringing has been conducted at the Kopań station $\left(54^{\circ} 28^{\prime} \mathrm{N}, 16^{\circ} 25^{\prime} \mathrm{E}\right)$. It was located $15 \mathrm{~km}$ to the NE from the Bukowo station, which was closed in 1984 because of habitat changes. As the habitats of Bukowo and Kopań were very similar, the ringing data from both stations were summed up and treated as collected at one station, called Bukowo-Kopań (Busse and Kania 1970, Remisiewicz and Baumanis 1996), "Bukowo" in short. The Bukowo-Kopań station is situated in a narrow belt of forest between the sea and wet meadows. The nets are placed in alder and pine forests, on meadows as well as in bushes close to small patches of reedbeds.

In our paper we also included, for a comparison, ringing data collected at the Drużno station $\left(54^{\circ} 05^{\prime} \mathrm{N}, 19^{\circ} 27^{\prime} \mathrm{E}\right)$, situated in the Lake Drużno Natural Reserve in NE Poland, close to village Stankowo, ca $35 \mathrm{~km}$ south from the Mierzeja Wiślana station. Lake Drużno is a vast, shallow ( $0.8 \mathrm{~m}$ deep on average), strongly eutrophic lake with considerable fluctuations of water level. The nets are placed in the swampy part of the lake, among extensive reedbeds - a habitat strongly preferred by the Acrocephalus warblers (Jakubas et al. 1999). The locations of all considered ringing stations are presented in Figure 1. 


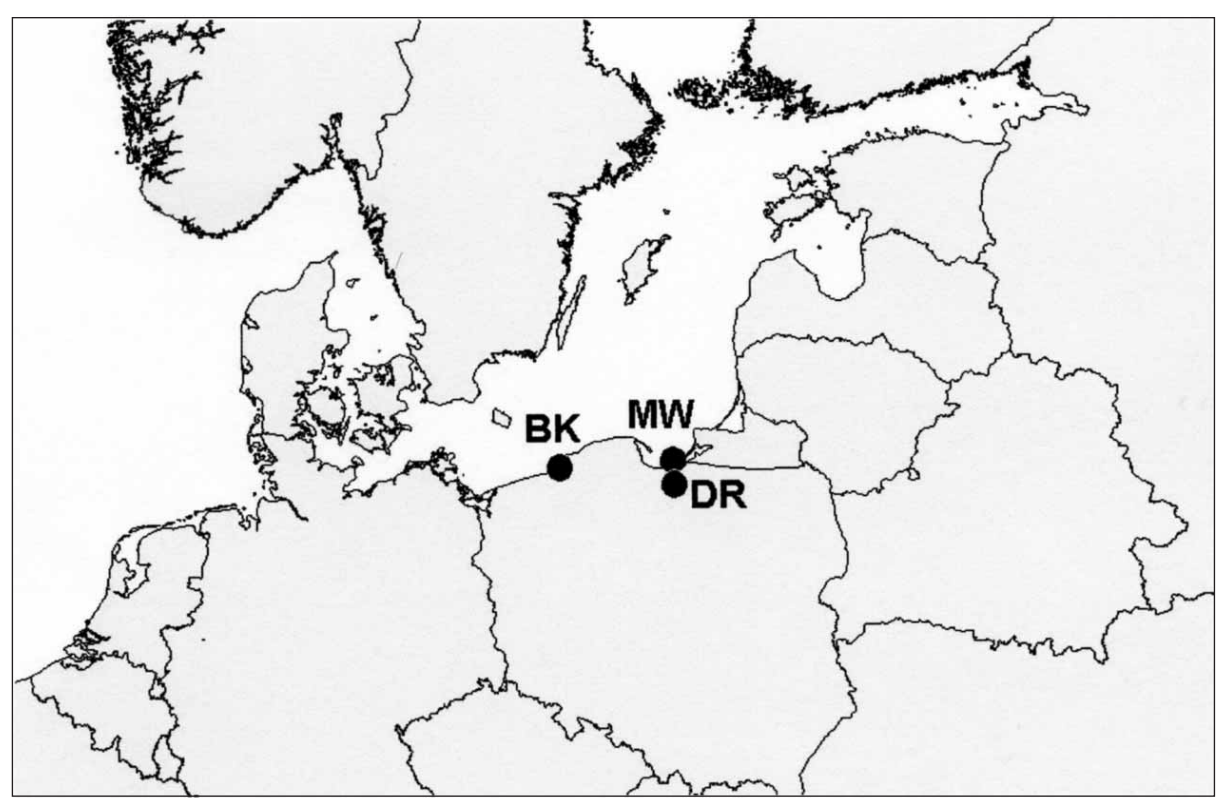

Fig. 1. Locations of the ringing stations: Bukowo-Kopań (BK), Mierzeja Wiślana (MW) and Drużno (DR).

\section{Fieldwork}

The birds were caught in mist-nets of 3 or 4 shelves, 7- or 12-m-long and 2-m-high. In the majority of seasons their number was 40-55 at Mierzeja and Bukowo, and 22-23 at Drużno. Every year the nets were placed generally in the same sites, and their numbers did not change throughout the season. The nets were controlled every hour from dawn till dusk. At Mierzeja the nets placed in the reedbeds (about 10-12 in number) were closed on 15 September.

The caught birds, after species identification, were sexed (if possible) and aged according to plumage features (Busse 1990a). Next, the biometrical measurements were taken - wing length, wing formula and tail length (using a ruler with the accuracy of $1 \mathrm{~mm}$ ), fat score (according to a 9-step scale) and weight (using a weighing scale with the accuracy of $0.5 \mathrm{~g}$, in recent years $0.1 \mathrm{~g}$ ). For a detailed description of methods and work routine of a field ringing station, see Busse and Kania (1970) and Busse (2000).

\section{Data analyses}

The dates of beginning and finishing the fieldwork at Bukowo and Mierzeja differed between individual years. Therefore, in order to compare the data from these two stations, we established the $\boldsymbol{1}^{\text {st }}$ standard period for 15 August -25 October. In the analyses, we used only the numbers of birds that were caught during this period. In 
the years when the fieldwork started after the beginning of the $1^{\text {st }}$ standard period or finished before its end, numbers for the "empty" days were counted proportionally to the numbers from the other years. The Aquatic Warbler, due to very small numbers of caught birds, was excluded from most of analyses.

For Drużno, also because of different time of the fieldwork in individual years, we established the $2^{\text {nd }}$ standard period for 2-30 August. We used the data from Drużno to illustrate the dynamics of migration of the Acrocephalus warblers before the beginning of the $1^{\text {st }}$ standard period. We also compared the dynamics at Drużno with the dynamics at Mierzeja for the 1995-1996 years, when the fieldwork at Mierzeja started exceptionally earlier (29 and 28 July, respectively); we made this comparison only for the Reed Warbler, as the numbers of other species were too low.

For all the studied species (except the Aquatic Warbler) we calculated long-term number dynamics and seasonal migration dynamics at Mierzeja and Bukowo. As a basis for the long-term dynamics we used the numbers of birds caught during the $1^{\text {st }}$ standard period in consecutive years. In order to obtain a more general illustration of number dynamics, we smoothed the numbers using a 5-year running average according to the formula:

$$
C_{w}=(a+2 b+3 c+2 d+e) / 9
$$

where:

$C_{w}$ - running average of birds' numbers in year $c$,

$a, b, c, d, e$ - numbers of birds caught in five consecutive years.

We calculated the coefficient of fluctuations, which is a measure of deviations of real numbers from the smoothed curve (Busse 2000). It was calculated according to the formula:

$$
C F=\left[\Sigma\left(X_{o y}-X_{y}\right)^{2} / N\right] / M \times 100 \%
$$

where:

$C F$ - coefficient of fluctuations,

$X_{y}$ - number of individuals in the year $y$,

$X_{o y}$ - moving average for the year $y$,

$N$ - number of study years,

$M \quad$ - average number for all the years.

We also checked, using Spearman's rank correlation, the relations between longterm number dynamics of individual species at Bukowo and Mierzeja.

We determined the seasonal migration dynamics using the total numbers of birds caught on the individual days of the standard period. The curves were then smoothed with a 5-day moving average as in the case of long-term dynamics. Next, we calculated, for every species at all the three stations, the median date of migration in the standard period, as well as the first and third quartiles. For the most numerous species, the Reed Warbler, we also found the median dates of migration in the individual years at all the stations (in the case of Bukowo only in the years when the total number of birds was higher than 70). For a more general illustration they were smoothed twice using the running average; the coefficients of fluctuations were calculated as well. We also checked, using linear regression, the relations between the median date and the year, the median date and the number of birds in the year, as well as the relations between median dates of migration at individual stations. 


\section{Discussion of methods}

The main bias of the applied methodology was the fact that the $1^{\text {st }}$ standard period at Bukowo and Mierzeja (and even the $2^{\text {nd }}$ standard period at Drużno) did not comprise the beginning of migration of the Acrocephalus warblers, which start their autumn migration as early as in July; therefore, the fraction of birds that migrated early was not caught at all. As a result, we were able to calculate the median dates only for the standard period and the observed fluctuations did not have to reflect the fluctuations in the median dates of the entire migration. Moreover, it was impossible to determine whether different numbers of birds caught in individual years really reflected the fluctuations in numbers of all migrating birds, or if they were only the result of shifting the time of migration, so more (or less) birds migrated during the standard period. Besides, the data from the first few years at Bukowo and Mierzeja were approximated to some extent, due to the start of the fieldwork after the beginning of the $1^{\text {st }}$ standard period. Changes in the location of the ringing stations and, as a consequence, changes of the habitat in the neighbourhood of the nets, could have resulted in greater or smaller differences in the intensity of bird catching. This referred especially to the early 1980s, when one of the ringing stations was moved from Bukowo, where nets were placed in reedbeds along the lakeside, to Kopań, where the reeds grew only in small patches. The lack of precise data about the numbers of nets placed in the reedbeds (these numbers differed between individual years) made it impossible to count the number of birds caught per unit of net length. This in consequence made it difficult to compare the catching results between stations as well as between different seasons at one station. Removing on 15 September the nets placed in the reedbeds at Mierzeja could have obscured the image of the end of migration at this station.

Among the Acrocephalus warblers there is a distinct overlap between the end of breeding season and the beginning of migration. Therefore, in the first days of the standard periods not only migrating but also local birds could have been caught. This referred especially to Mierzeja and Drużno, where birds could find suitable breeding sites among vast reedbeds. At Mierzeja the nests of Reed Warblers were found as late as in the second half of August (Busse 1965). In our paper we did not analyse the changes of fat level of caught individuals; therefore it was impossible to distinguish between migrating and local birds, which made the seasonal migration dynamics biased.

In spite of the methodological biases mentioned above, a detailed analysis of the material showed the results presented below. It should be noted though, that the obtained image of the Acrocephalus warblers' passage through the Polish Baltic coast is only an approximation of their real migration.

\section{RESULTS}

The most numerous species caught at Bukowo and Mierzeja was the Reed Warbler - at both stations it constituted ca $85 \%$ of all the Acrocephalus warblers. The Marsh Warbler was the only species that was more abundant at Bukowo than at the 
other stations (Table 4). At Drużno the most numerous species were the Reed and Sedge Warblers; the disproportion in numbers between them is much lower than at Bukowo or Mierzeja. The rarest species caught was the Aquatic Warbler - only 14 individuals were caught during all the years.

Table 4

The comparison between Bukowo-Kopań and Mierzeja Wiślana with regard to the percentages of Acrocephalus warblers caught in all the years at these stations

\begin{tabular}{|l|c|c|}
\hline \multicolumn{1}{|c|}{ Species } & Bukowo-Kopań (\%) & Mierzeja Wiślana (\%) \\
\hline Acrocephalus scirpaceus & 24 & 76 \\
Acrocephalus schoenobaenus & 13 & 87 \\
Acrocephalus palustris & 72 & 28 \\
Acrocephalus arundinaceus & 13 & 87 \\
Acrocephalus paludicola & 14 & 86 \\
\hline
\end{tabular}

Long-term number dynamics are shown in Figure 2. Large fluctuations of the curves are quite remarkable. At both stations for all the species a high peak of abundance at the beginning of the $\mathrm{XXI}^{\text {th }}$ century can be observed, when numbers were even ten times higher than the average in 1962-1970. At Bukowo this peak is preceded by a period of very low numbers in the 1980s and 1990s. In the earlier years one can observe a high peak of the Reed Warbler numbers, a lower one in the case of the Sedge and Great Reed Warblers, and rather regular cyclic changes (small peaks) in the Marsh Warbler numbers. At Mierzeja there are no such long periods of low numbers for the analysed warblers, instead there is another distinct peak of abundance in the 1980s (except for the Reed Warbler with a less distinct one in the 1970s), and also a third one in the 1960s for the Sedge and Great Reed Warblers. The deviations of the raw numbers from the smoothed curve differ between the species and they are especially high at Bukowo (high values of $C F$ ), which suggests large fluctuations of the migrating birds' numbers in consecutive years. There are high correlations between the long-term number dynamics of individual species at the same station, particularly those strongly preferring reeds (the Reed, Sedge and Great Reed Warblers; Table 5).

Seasonal migration dynamics in the $1^{\text {st }}$ standard period at Bukowo and Mierzeja are shown in Fig. 3. They are similar for all the species: one can observe the peak of migration in the very beginning of the standard period or just after it, and then the numbers decrease. This decrease can be fast (the Great Reed and Marsh Warblers) or slower (the Reed and Sedge Warblers), it can even be broken by small cyclic peaks. The Marsh and Great Reed Warblers migrate through Bukowo and Mierzeja quite early (median dates between 22 and 25 August), the migration of the Reed and Sedge Warblers is more prolonged (median dates between 26 and 30 August), especially at Bukowo, where the last Reed Warblers are still caught in the middle of October. For all the species except the Great Reed Warbler, the median date of migration is earlier at Mierzeja. As for the Aquatic Warbler, all individuals were caught in a period shorter than a month, from 18 August till 14 September. 

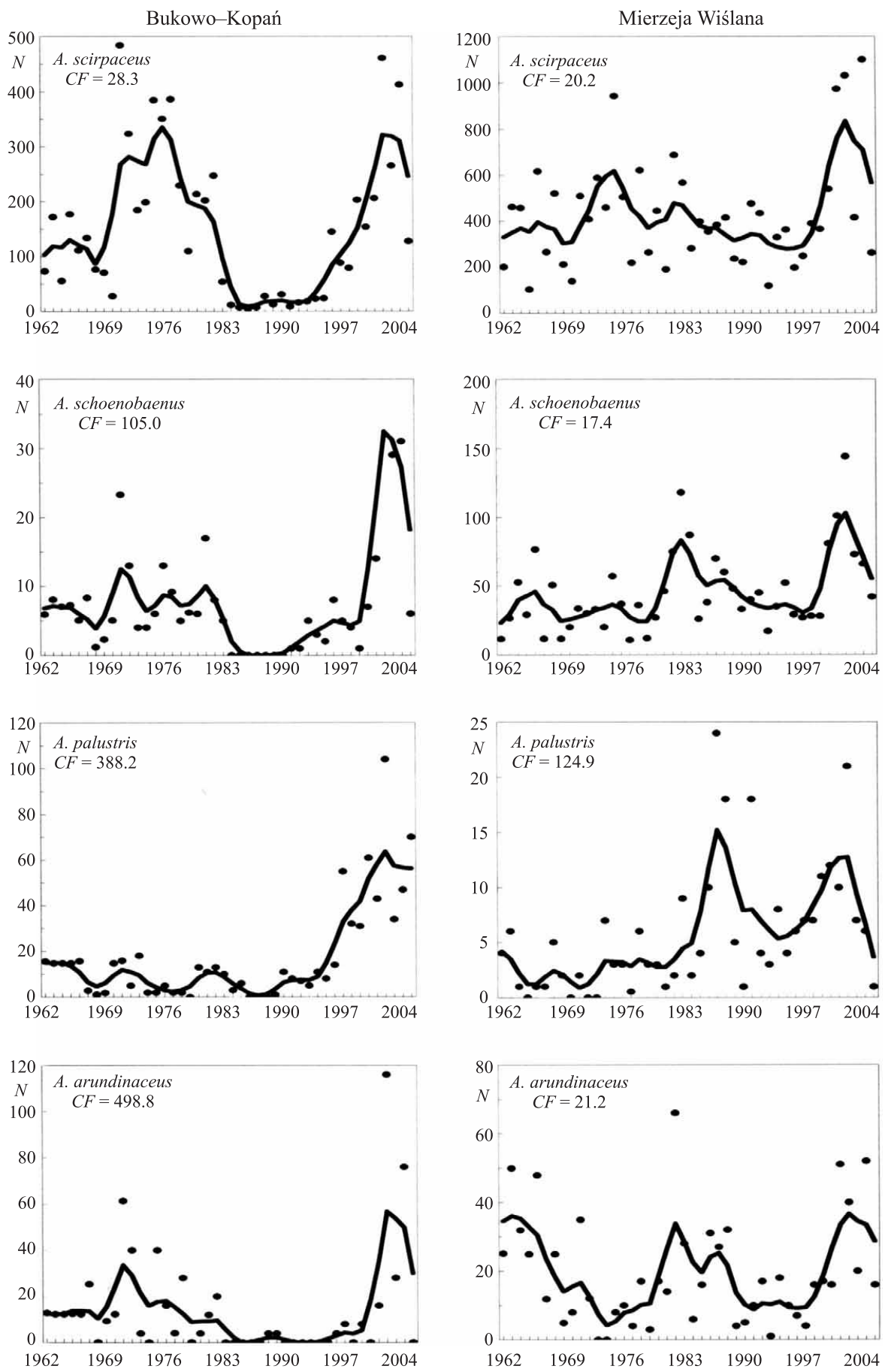

Fig. 2. Long-term number dynamics of the Reed, Sedge, Marsh and Great Reed Warblers at Bukowo-Kopań and Mierzeja Wiślana in the $1^{\text {st }}$ standard period. Raw numbers are pictured by dots, smoothed values by the curve. $C F-$ coefficient of fluctuations. 
THE RING 31, 2 (2009)

25
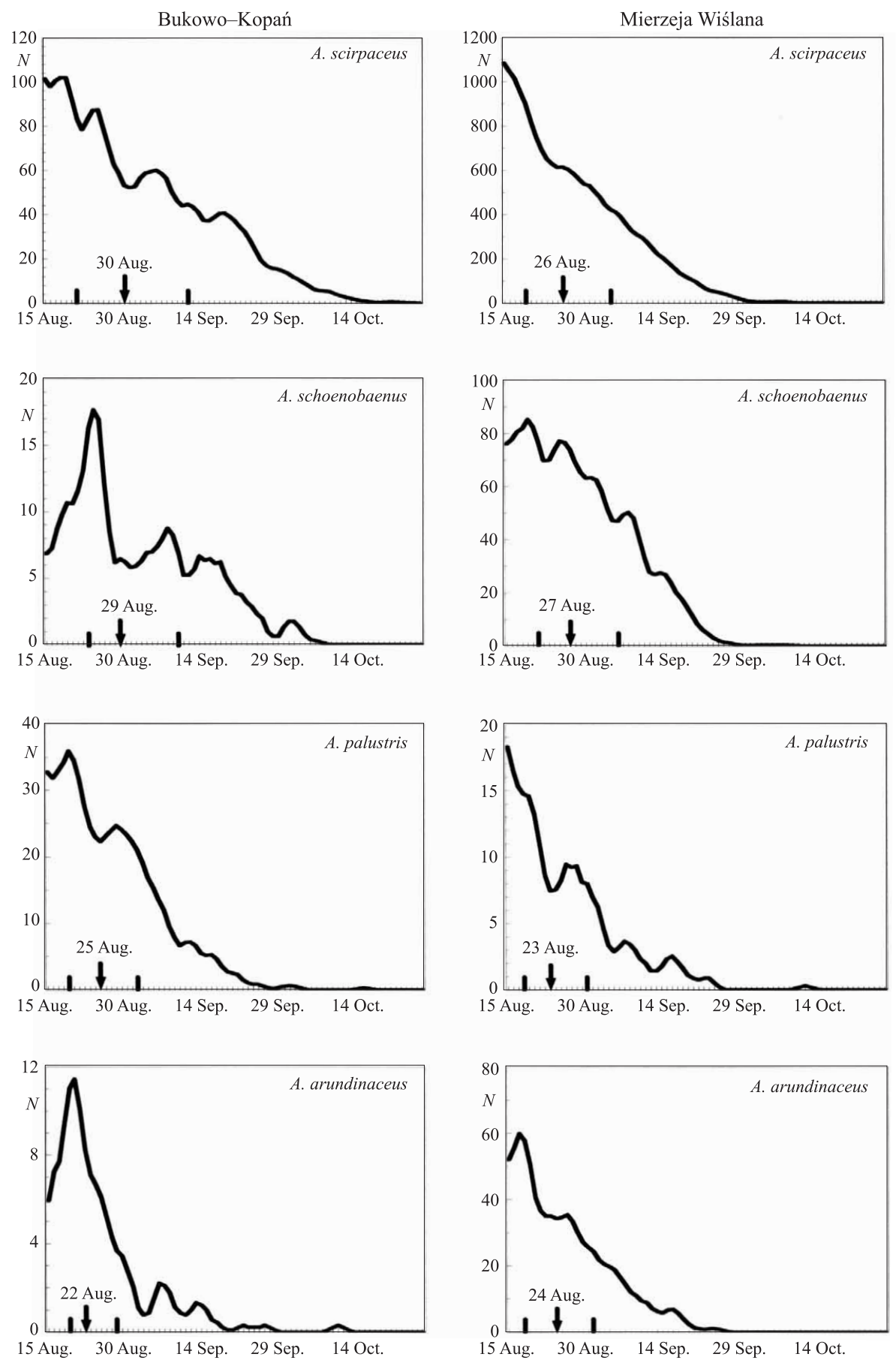

Fig. 3. Smoothed seasonal migration dynamics of the Reed, Sedge, Marsh and Great Reed Warblers at Bukowo-Kopań and Mierzeja Wiślana in the $1^{\text {st }}$ standard period. The median dates are indicated by arrows, the first and third quartiles by strokes. 
Table 5

Coefficients of Spearman's rank correlations between long-term numbers of individual Acrocephalus species at Bukowo-Kopań, at Mierzeja Wiślana and between these two stations. Statistically significant values are in bold.

\begin{tabular}{|c|c|c|c|c|}
\hline \multicolumn{5}{|c|}{ Bukowo-Kopań } \\
\hline & ACR.IRP & ACR.ENO & ACR.UST & ACR.ARU \\
\hline ACR.IRP & $\times$ & $\mathbf{0 . 8 1} * * * *$ & $\mathbf{0 . 3 9 * *}$ & $\mathbf{0 . 7 5 * * * *}$ \\
\hline ACR.ENO & & $\times$ & $\mathbf{0 . 4 2} * *$ & $\mathbf{0 . 6 3} * * * *$ \\
\hline ACR.UST & & & $\times$ & $\mathbf{0 . 3 3}$ \\
\hline
\end{tabular}

\begin{tabular}{|c|c|c|c|c|}
\hline \multicolumn{5}{|c|}{ Mierzeja Wiślana } \\
\hline & ACR.IRP & ACR.ENO & ACR.UST & ACR.ARU \\
\hline ACR.IRP & $\times$ & $\mathbf{0 . 6 1} * * * *$ & $\mathbf{0 . 3 0}$ & $\mathbf{0 . 4 9} * * *$ \\
\hline ACR.ENO & & $\times$ & $\mathbf{0 . 3 4}$ & $\mathbf{0 . 4 8} * * *$ \\
\hline ACR.UST & & & $\times$ & $\mathbf{0 . 2 7}$ \\
\hline
\end{tabular}

\begin{tabular}{|c|c|c|c|c|c|}
\hline & \multicolumn{5}{|c|}{ Mierzeja Wiślana } \\
\hline \multirow{4}{*}{ Bukowo-Kopań } & & ACR.IRP & ACR.ENO & ACR.UST & ACR.ARU \\
\cline { 2 - 6 } & ACR.IRP & $\mathbf{0 . 4 1 * *}$ & & & \\
\cline { 2 - 6 } & ACR.ENO & & 0.08 & & \\
\cline { 2 - 6 } & ACR.UST & & & 0.23 & \\
\cline { 2 - 6 } & ACR.ARU & & & & $\mathbf{0 . 1 0}$ \\
\hline
\end{tabular}

Species codes as in Table 1 .

$* 0.01<p<0.05, * * 0.001<p<0.01,{ }^{* * *} 0.0001<p<0.001,{ }^{* * * *} p<0.0001$.

Seasonal dynamics at Drużno (Fig. 4) suggest that birds migrate as early as in the first half of August, before the beginning of the $1^{\text {st }}$ standard period. Median dates of migration at Drużno occur between 11 and 14 August with the peaks of migration in the beginning of August. As for the Sedge Warbler, the peak probably occurs even earlier, before the beginning of the $2^{\text {nd }}$ standard period. Similarly at Mierzeja in 1995-1996 one can observe the migration of the Reed Warbler before the beginning of the $1^{\text {st }}$ standard period (Fig. 5).

Figures showing median dates of the Reed Warbler passage within the $1^{\text {st }}$ standard period (Fig. 6) reveal considerable fluctuations of migration terms over the years of study. The range between extreme median dates at Bukowo is 23 days, whereas at Mierzeja - 15 days. At Bukowo, in the 1970s one can observe cyclic fluctuation of the median dates; in recent years the medians tend to occur earlier. At Mierzeja, they occur later (statistically significant trend: $r=0.43, p=0.003$ ). Median dates in the $2^{\text {nd }}$ standard period also show large variability $(C F=73.8)$. We have not found statistically significant relationships between the medians and the years at Bukowo and Drużno $(r=-0.14, p=0.45$ and $r=-0.21, p=0.46$, respectively), nor between the median dates and the numbers of birds caught at any station (Bukowo: $r=-0.29, p=0.11$; Mierzeja: $r=0.12, p=0.43$; Drużno: $r=-0.13, p=0.65)$. There is also no statistically significant correlation between the median dates at Bukowo and Mierzeja $(r=0.27$, $p=0.13)$, nor at Mierzeja and Drużno $(r=0.26, p=0.34)$. 

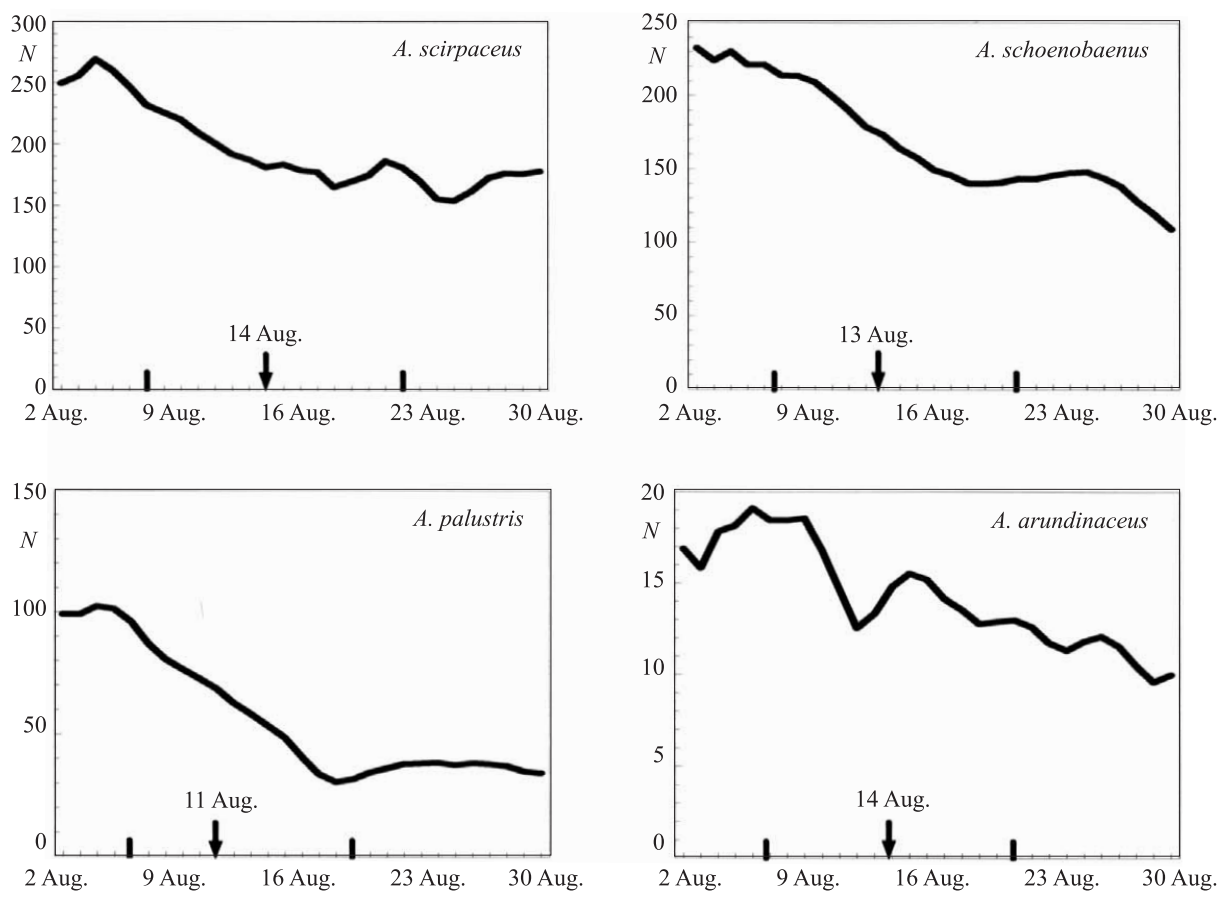

Fig. 4. Smoothed seasonal migration dynamics of the Reed, Sedge, Marsh and Great Reed Warblers at Drużno in the $2^{\text {nd }}$ standard period. The median dates are indicated by arrows, the first and third quartiles by strokes.

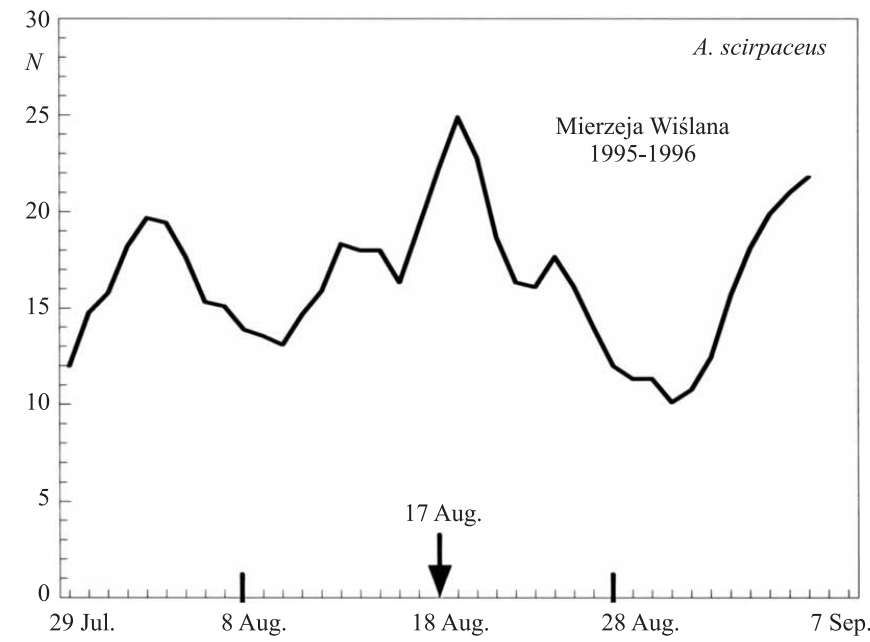

Fig. 5. Smoothed seasonal migration dynamic of the Reed Warbler at Mierzeja Wiślana in the $2^{\text {nd }}$ standard period in 1995-1996. The median date is indicated by an arrow, the first and third quartiles by strokes. 

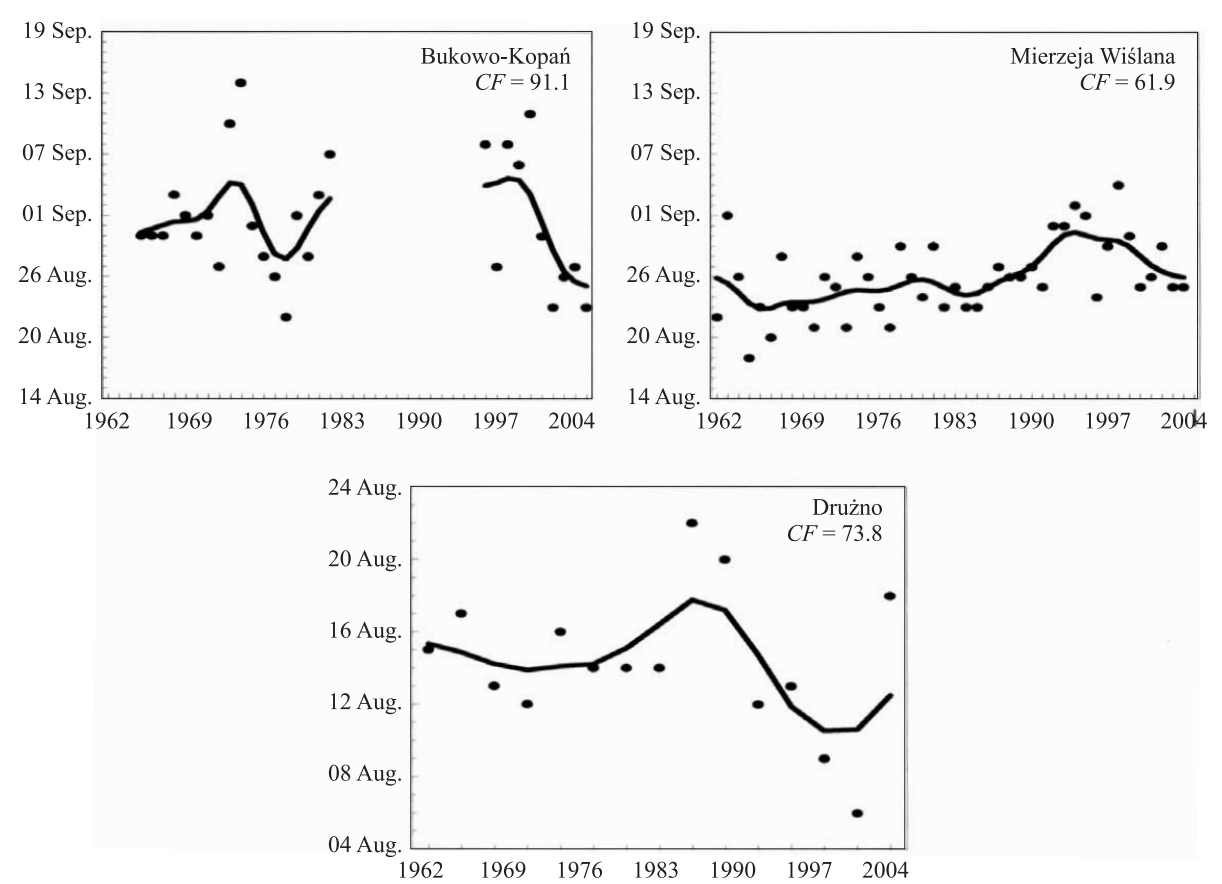

Fig. 6. Long-term changes of median dates of the Reed Warbler migration at Bukowo-Kopań and Mierzeja Wiślana in the $1^{\text {st }}$ standard period and at Drużno in the $2^{\text {nd }}$ standard period. Raw dates are pictured by dots, smoothed values by a curve. $C F$ - coefficient of fluctuations.

\section{DISCUSSION}

Analyses of long-term number dynamics and seasonal migration dynamics reveal distinct similarities between the migration of individual Acrocephalus species at Mierzeja and Bukowo. In the case of long-term dynamics it should be noted that increases and decreases in numbers of the individual species occur more or less simultaneously at a given station. Similarities between the stations can be observed as well $-e . g$. both at Mierzeja and Bukowo a high peak of abundance occurs at the beginning of the XXI ${ }^{\text {st }}$ century for all the species. Generally, the long-term number dynamics of the considered species show marked variability, being subjected to large fluctuations in consecutive years (high values of the coefficients of fluctuations). These fluctuations could result either from the methodology (see Discussion of methods) or from other factors, like weather conditions in the breeding and post-breeding season, habitat changes or population cycles (Busse 1973).

If we assume that the long-term dynamics reflect real changes in numbers of migrating birds, and not only the shifts of the time of migration, there are two hypotheses that explain this phenomenon: 1) the influence of climate and habitat changes (Berthold 1972 after Busse and Cofta 1986, Cotton 2003), 2) the presence of longterm population cycles (Busse 1973). As for the first hypothesis, climate changes may 
cause various weather perturbations, e.g. cold and rainy springs, causing increased mortality of nestlings, or droughts decimating bird numbers at their winter quarters. A long time can pass before the population numbers reach previous level, which could be reflected in the long-term dynamics. On the other hand, favourable conditions on breeding and wintering grounds contribute to increased survival rate and, as a result, a higher number of individuals breeding in the next season. Studies on the Sedge Warbler revealed a strong correlation between the numbers of this species in Great Britain and the Netherlands and the amount of rainfall at its winter quarters in West Africa (Peach et al. 1991, Foppen et al. 1999). However, this correlation was not valid for the Reed Warbler (Thaxter et al. 2006). Habitat changes due to human activity, especially habitat fragmentation, can influence bird numbers as well: in the Netherlands after a rapid decrease in numbers, populations of the Sedge Warbler inhabiting fragmented wetlands did not recover, unlike populations from denser marshes (Foppen et al. 1999). Reed harvesting may also have a negative influence on the numbers of Acrocephalus warblers during the breeding season (Goc et al. 1997). The impact of habitat changes on population numbers is especially striking in the case of the Aquatic Warbler, which bred (although scarcely) on the whole Polish lowland in the past, but recently has abandoned most regions due to drainage of marshes and nowadays it breeds only at a few sites (Tomiałojć and Stawarczyk 2003).

On the other hand, changes in numbers may reflect long-term population cycles, observed also in other species, e.g. the Goldcrest (Regulus regulus) (Busse 1990b) or Great Tit (Parus major) (McCleery and Perrins 1991). These cycles can last very long, like in the case of two species of Siberian thrushes: the Naumann's Thrush (Turdus naumanni) and Dusky Thrush (T. eunomus), which are vagrants in Europe regularly every 50 years (Machalska et al. 1969). Various environmental factors may be responsible for these cycles, especially predation and availability of food resources (McCleery and Perrins 1991). Long-term changes of population numbers of the Acrocephalus warblers during migration were also noted in other places in Europe, e.g. in Hungary, where numbers of Sedge Warblers, after a peak in 1984, were decreasing until 1993 (Guryacz and Bank 1998).

Highly significant correlations between the numbers of Acrocephalus species at Bukowo and Mierzeja suggest that the fluctuations of long-term number dynamics have common basis. The highest correlations are observed between the Reed, Sedge and Great Reed Warblers. These three species prefer similar habitats - in the breeding season they inhabit open wetlands with domination of the Common Reed (Phragmites communis) and Reed-mace (Typha latifolia), whereas in winter quarters they occur, though not invariably, in humid places (Cramp 1992). All these species may therefore react to changes of breeding or wintering habitat in similar ways, by number changes or by simultaneous changes of migration terms. Similar correlations for numbers of migrants, this time irruptive, were found for Swiss tits (KornerNievergelt et al. 2008).

As for the seasonal dynamics, it should be noted that peaks of migration for all the species occur in the beginning of the $1^{\text {st }}$ standard period both at Bukowo and Mierzeja. However, seasonal dynamics at Drużno suggest that peaks of the overall migration occur earlier, even before the beginning of the $1^{\text {st }}$ standard period at Drużno, al- 
though it starts 2 weeks earlier than at Bukowo and Mierzeja. It should be noted, though, that seasonal dynamics in late July / early August may include local individuals, adults finishing breeding season as well as their offspring. On the contrary, the end of migration is clearly visible both at Bukowo and Mierzeja - migration of all the species finishes in the $2^{\text {nd }}$ half of September, for the Great Reed and Marsh Warblers sooner than for the Reed and Sedge Warblers, which corresponds with data from the whole of Poland (Tomiałojć and Stawarczyk 2003).

Median dates of migration for all the species (except the Great Reed Warbler) at Bukowo follow the dates at Mierzeja, probably due to the fact that Bukowo lies farther to the west - if the same birds migrate through both the stations, they will arrive at Bukowo later. Recoveries (Busse 2001) and results of orientation tests (Trocińska et al. 2001, Formella and Busse 2002) on the Reed and Sedge Warblers support this hypothesis and show that different populations of both species migrate in different directions. It was found that European Reed Warblers migrate in either south-western or south-eastern direction. Birds from the Baltic Sea basin, including those from Mierzeja, take south-western route (Trocińska et al. 2001); therefore they arrive at Bukowo later than at Mierzeja. This assumption is also supported by statistically significant correlation between long-term number dynamics of Reed Warblers at both stations. In the case of Aquatic Warblers, recoveries of birds ringed in the Biebrza Marshes and later caught in Western Europe also suggest the west direction in the first stage of their migration (Dyrcz 1992). In addition, Reed Warblers tested in orientation cages at Bukowo preferred south-eastern direction (Trocińska et al. 2001) - such birds probably migrate from Scandinavia. Their presence at Bukowo may be one of the reasons for differences between seasonal dynamics at Bukowo and Mierzeja. At Drużno most Reed and Sedge Warblers chose the south direction with deviation to south-west (Trocińska et al. 2001). Due to vicinity of Mierzeja and Drużno one can assume that the dynamics and main directions of migration will be similar at both these stations. In the case of the Great Reed Warbler the median date of migration at Bukowo precedes the date at Mierzeja; it is possible that through each of these stations migrate birds from different populations.

While comparing long-term number dynamics and seasonal migration dynamics between stations, one should bear in mind the habitats of the stations. At Bukowo, the habitat structure is different than at the other two stations - there are only a few patches of reedbeds, and many nets are placed close to bushes. This kind of habitat is strongly preferred by the Marsh Warbler, which is the only species that is more numerous at Bukowo than at the two other stations. For other species Mierzeja and Drużno are more suitable; this refers particularly to the Sedge Warbler. The species is highly dependent on reeds during migration because of the Mealy Plum Aphid (Hyalopterus pruni), which is the main source of food then (Bibby and Green 1981). The Sedge Warbler is much more numerous at Mierzeja than at Bukowo; however, its proportion in all caught birds is rather small and similar at both these stations (4 and $9 \%$, respectively), whereas at Drużno, with similar habitat to Mierzeja, it is as high as $39 \%$. This is due to the fact that fieldwork at Mierzeja and Bukowo starts relatively late. The autumn migration of Sedge Warblers in Europe begins early - in southern Finland the migration of adult birds starts in the first half of July, peaks at the end of 
July and finishes in mid-August; the migration peak of immature birds occurs at the beginning of August (Koskimies and Saurola 1985), whereas in southern Sweden in the second half of July (Hall 1996). In the Czech Republic the migration of adult and immature birds peaks in the second half of July and in the first half of August, respectively (Literak et al. 1994). One can assume that in Poland the beginning and peak of migration should occur in similar time. Farther south in northern Italy, for a comparison, the median date of the migration of adults is 12-13 August, and of immatures - 18-19 August (Basciutti et al. 1997). At Drużno, where fieldwork used to begin two weeks earlier than at Bukowo and Mierzeja, the disproportion between the numbers of Reed and Sedge Warblers was distinctly smaller - the difference was only 6\%, whereas at Bukowo and Mierzeja -81 and $77 \%$, respectively. It can be assumed that earlier beginning of fieldwork at Bukowo and Mierzeja would lead to the decrease of this disproportion.

The median dates of migration of the Reed Warbler in consecutive years show fluctuations, distinct especially at Bukowo. At Mierzeja these dates are delayed and this trend is statistically significant. Such long-term changes of the migration terms may be connected with climate changes. In Great Britain it was found that 30 bird species (including the Reed and Sedge Warblers) shifted their mean dates of arrival and departure as greatly as 8 days towards the earlier dates during the last 30 years (Cotton 2003); the author relates this phenomenon to the global warming. In France since 1980 the peaks of autumn migration of the Reed and Sedge Warblers have shifted towards the earlier dates as well; this shift was correlated with the temperatures of March - the peak occurred earlier in the years with a warmer spring (Péron et al. 2007). The authors suggest that birds benefit more from reaching winter quarters as soon as possible and thus being able to occupy better territories, than from staying longer on breeding grounds. It is probable that climate changes are responsible also for the changes of median dates observed at Bukowo and Mierzeja; however, there are no distinct shifts towards the earlier dates (only at Bukowo such a shift can be noticed in the last few years; at Mierzeja the overall trend is even the opposite). It should also be noted that these median dates are calculated only for the $1^{\text {st }}$ standard period and a fraction of birds that migrate earlier is omitted then. Therefore, we are not able to tell how the observed trends reflect changes in the median dates of the overall migration period: whether the migration really shifts in time or it is just more or less prolonged. It is probable that the migration of the Acrocephalus warblers indeed undergoes cyclic changes of terms in consecutive years, which may be triggered by both climate changes and, connected with them, changes in the availability of food resources (Ciach 2007).

To sum up, the migration of the Acrocephalus warblers through the Polish Baltic coast displays considerable long-term variability, which cannot be entirely explained so far. Most probably, combined climatic and habitat factors are responsible for it. For more detailed studies and explanations it is essential to use more complex analyses, which include biometry and orientation tests. It would also be beneficial to begin the fieldwork at the stations earlier, (especially at Mierzeja and Drużno), preferably starting from mid-July, so as to comprise the whole period of the Acrocephalus warblers migration and thus be able to study its phenology more thoroughly. 


\section{ACKNOWLEDGEMENTS}

We would like to express our gratitude to Dariusz Jakubas, Beata Michno, Czesław Nitecki and other members of the Drużno ringing team, who kindly allowed us to use the ringing data from the Drużno station. We also thank Jarosław K. Nowakowski and Agnieszka Ożarowska for their valuable comments on the script. Last but not least, we are grateful to all the ringers and volunteers taking part in ringing activities at the Bukowo-Kopań and Mierzeja Wiślana stations.

\section{REFERENCES}

Basciutti P., Negra O., Spina F. 1997. Autumn migration strategies of the Sedge Warbler Acrocephalus schoenobaenus in northern Italy. Ring. \& Migr. 18, 1: 59-67.

Berthold P. 1972. Über Rückgangserscheinungen und deren mögliche Ursachen bei Singvögeln. Vogelwelt 92: 216-226.

Bibby C.J., Green R.E. 1985. Autumn migration strategies of Reed and Sedge Warblers. Ornis Scand. 12: 1-12.

Busse P. 1965. Late broods of the Reed Warbler Acrocephalus scirpaceus (Herm.) in 1964. Not. Orn. 6, 1: 20 .

Busse P. 1973. Number dynamics of some bird species caught at the Polish Baltic coast in the years 1961-1970. Not. Orn. 14, 1-2: 1-28.

Busse P. 1990a. Key to sexing and ageing of European passerines. Not. Orn. 31, 5: 1-364.

Busse P. 1990b. Studies of long-term population dynamics based on ringing data. Ring 13, 1-2: 221-234.

Busse P. 1994. Population trends of some migrants at the southern Baltic coast-autumn catching results 1961-1990. Ring 16, 1-2: 115-158.

Busse P. 2000. Bird Station Manual. SEEN. University of Gdańsk, Gdańsk.

Busse P. 2001. European passerine migration system - what is known and what is lacking? Ring 23, 1-2: 3-36.

Busse P., Cofta T. 1986. Population trends of migrants at the Polish Baltic coast and some new problems in the interpretation of migration counts. Vår Fågelv. 11, Suppl.: 27-31.

Busse P., Halastra G. 1981. Autumn bird migration at the Polish Baltic Coast. Acta Orn. 18, 3: 1-122.

Busse P., Kania W. 1970. Operation Baltic 1961-1967. Working methods. Acta Orn. 12, 7: 232-267.

Ciach M. 2007. [Migration dynamics of the Chiffchaff Phylloscopus collybita (Vieillot, 1817) and the Willow Warbler Phylloscopus trochilus (Linnaeus, 1758) along the East European migration route.] Ph.D. thesis, Univ. of Agriculture in Krakow, Poland. (In Polish).

Cotton P. 2003. Avian migration phenology and global climate change. Proc. Natl. Acad. Sci. USA 100, 21: 12219-12222.

Cramp S. (Ed.). 1992. Handbook of the Birds of Europe, the Middle East and North Africa. The Birds of Western Palearctic. vol. 6. Oxford Univ. Press, Oxford.

Dyrcz A. 1992. Recoveries of the Aquatic Warblers (Acrocephalus paludicola) ringed on the Biebrza marshes. Not. Orn. 33, 3-4: 336-337.

Foppen R., ter Braak C.J.F., Verboom J., Reijnen R. 1999: Dutch Sedge Warblers Acrocephalus schoenobaenus and West-African rainfall: empirical modeling show low population resilience in fragmented marshlands. Ardea 87, 1: 113-127. 
Formella M., Busse P. 2002. Directional preferences of the Reed Warbler (Acrocephalus scirpaceus) and the Sedge Warbler (A. schoenobaenus) on autumn migration at Lake Druzno (N Poland). Ring 24, 2: 15-30.

Goc M., Iliszko L., Kopiec K. 1997: The effect of Reed harvesting on reedbird birds community. Ring 19, 1-2: 135-148.

Gyuracz J., Bank L. 1998. Monitoring of Sedge Warbler (Acrocephalus schoenobaenus) during autumn migration in southern Hungary. Aquila 103-104: 59-66.

Hall S. 1996: The timing of post-juvenile moult and fuel deposition in relation to the onset of autumn migration in Reed Warblers Acrocephalus scirpaceus and Sedge Warblers Acrocephalus schoenobaenus. Ornis Svec. 6: 89-96.

Jakubas D., Michno B., Nitecki C., Strawiński S., Ulatowska J. 1999. Ringing of passerines in the „Druzno Lake” reserve in 1990-1999. Ring 21, 2: 173-178.

Korner-Nievergelt F., Korner-Nievergelt P., Baader E., Fischer L., Schaffner W., Kestenholz M. 2008: Between-species correlations in the number of migrants at Ulmethöchi (Switzerland). J. Ornithol. 149: 579-586.

Koskimies P., Saurola P. 1985. Autumn migration strategies of the Sedge Warbler Acrocephalus schoenobaenus in Finland: a preliminary report. Ornis Fenn. 62, 4: 145-152.

Literak I., Honza M., Kondelka D. 1994. Postbreeding migration of the Sedge Warbler Acrocephalus schoenobaenus in the Czech Republic. Ornis Fenn. 71: 151-155.

Machalska J., Kania W., Hołyński R. 1969. The new specimen of Dusky Thrush In Poland and occurence of Turdus naumanni (sensu lato) in Europe. Not. Orn. 8, 2-3: 25-32.

McCleery R.H., Perrins C.M. 1991: Effects of predation on the numbers of Great Tits Parus major. In: Perrins C.M., Lebreton J.-D., Hirons G.J.M. (Eds). Bird population studies. Oxford Univ. Press, Oxford, pp. 129-147.

Peach W., Baillie S., Underhill L. 1991: Survival of British Sedge Warblers Acrocephalus schoenobaenus in relation to west African rainfall. Ibis 133: 300-305.

Péron G., Henry P., Provost P., Dehorter O., Julliard, R. 2007. Climate changes and post-nuptial migration by two reedbed passerines. Clim. Res. 35: 147-157.

Remisiewicz M., Baumanis J. 1996. Autumn migration of Goldcrest (Regulus regulus) at the eastern and southern Baltic coast. Ring 18, 1-2: 3-35.

Szostakowski J. 1989. Migration dynamics and long-term population dynamics of Reed Warblers migrating in autumn through Polish Baltic coast. Not. Orn. 30, 1-2: 3-19.

Thaxter C.B., Redfern C.P.F., Bevan R.M. 2006: Survival rates of adult Reed Warblers Acrocephalus scirpaceus at a northern and southern site in England. Ring. \& Migr. 23: 65-79.

Tomiałojć L., Stawarczyk T. 2003. Awifauna Polski. Rozmieszczenie, liczebność i zmiany. PTPP "pro Natura", Wrocław.

Trocińska A., Leivits A., Nitecki C., Shydlovsky I. 2001. Field studies of directional preferences of the Reed Warbler (Acrocephalus scirpaceus) and the Sedge Warbler (A.schoenobaenus) of autumn migration along the eastern and southern coast of the Baltic Sea and in western part of Ukraine. Ring 23, 1-2: 109-117. 
APPENDIX

Acrocephalus scirpaceus - Bukowo-Kopań
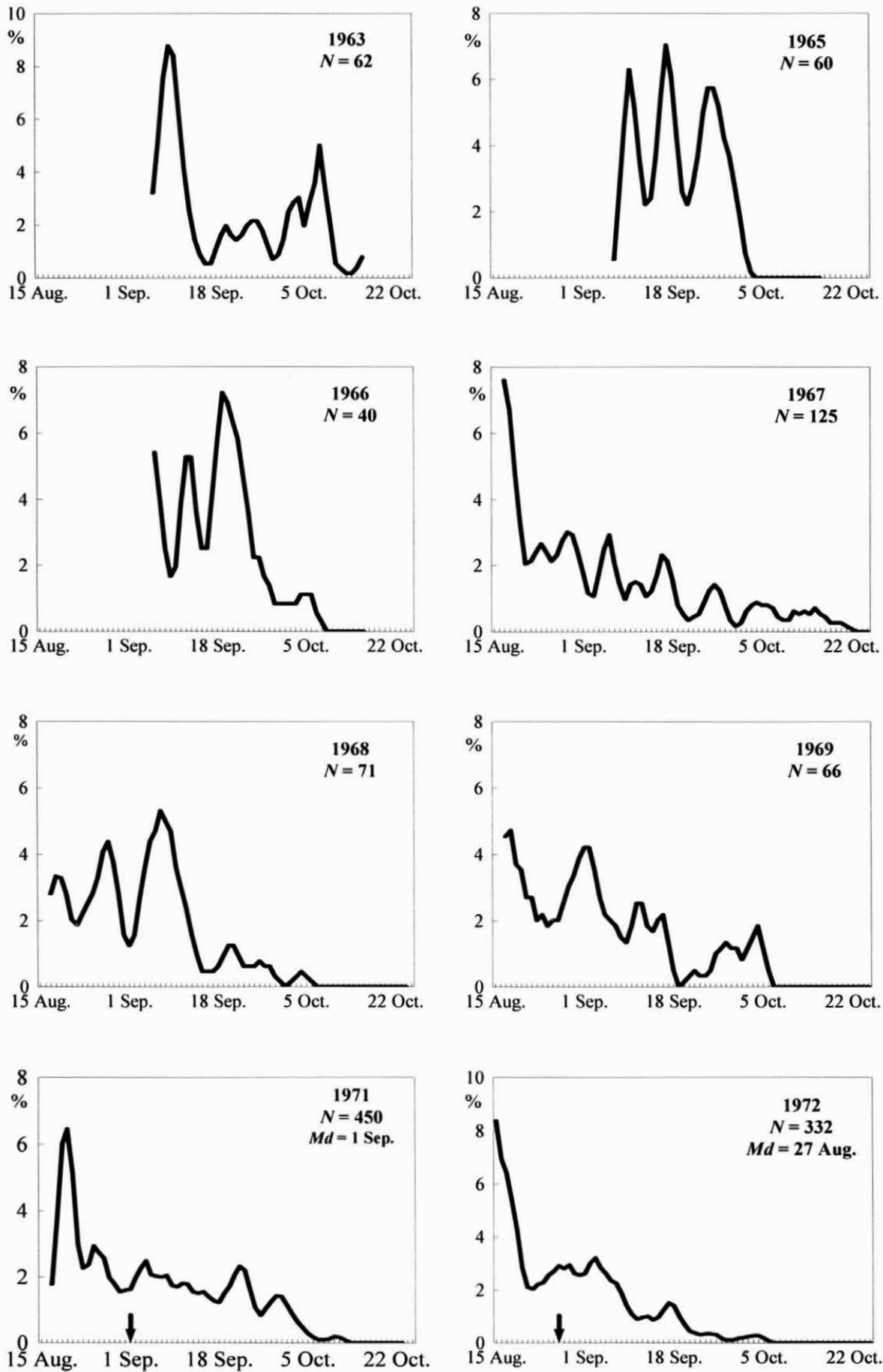
APPENDIX

Acrocephalus scirpaceus - Bukowo-Kopań
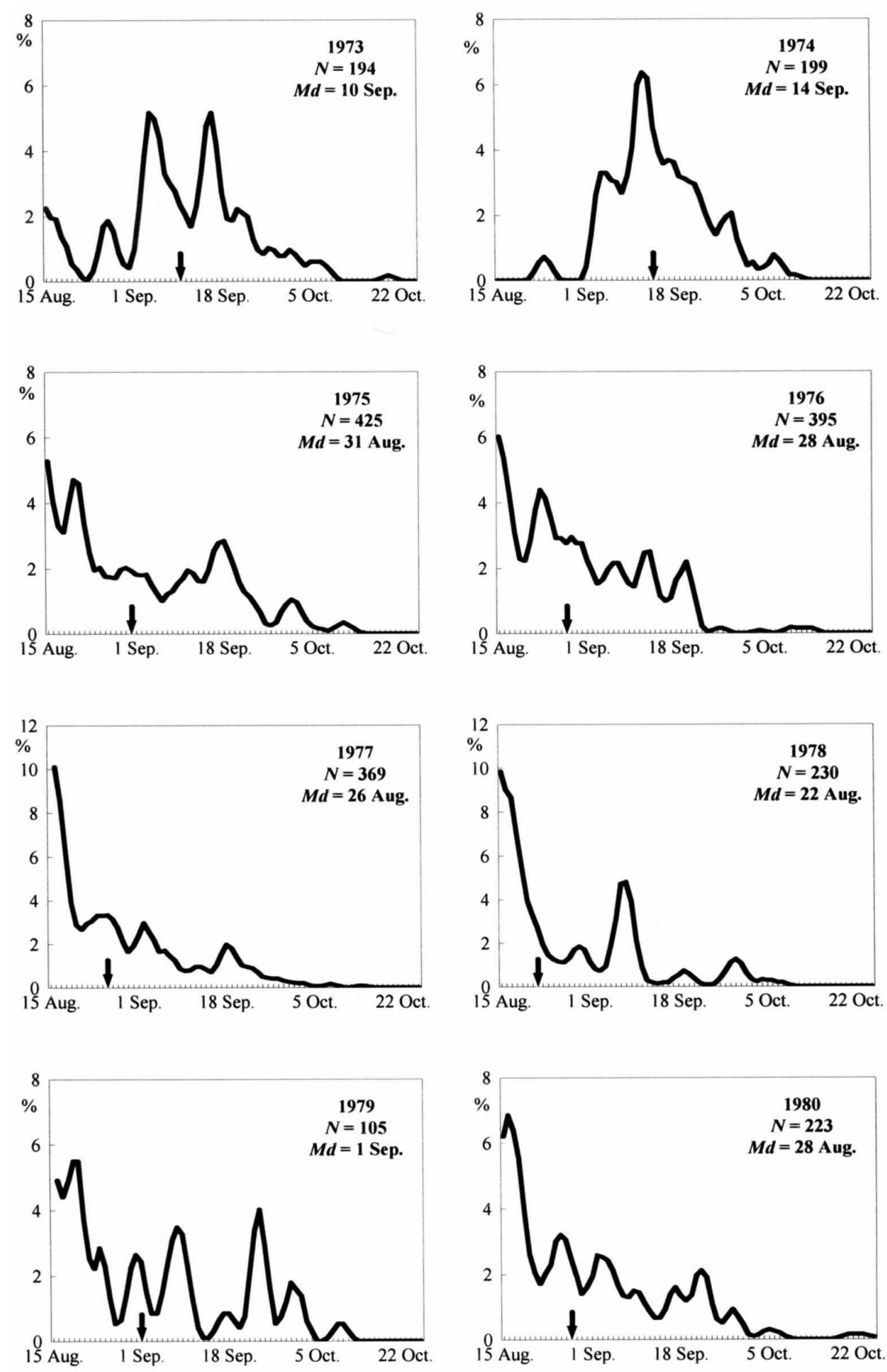
APPENDIX

Acrocephalus scirpaceus - Bukowo-Kopań
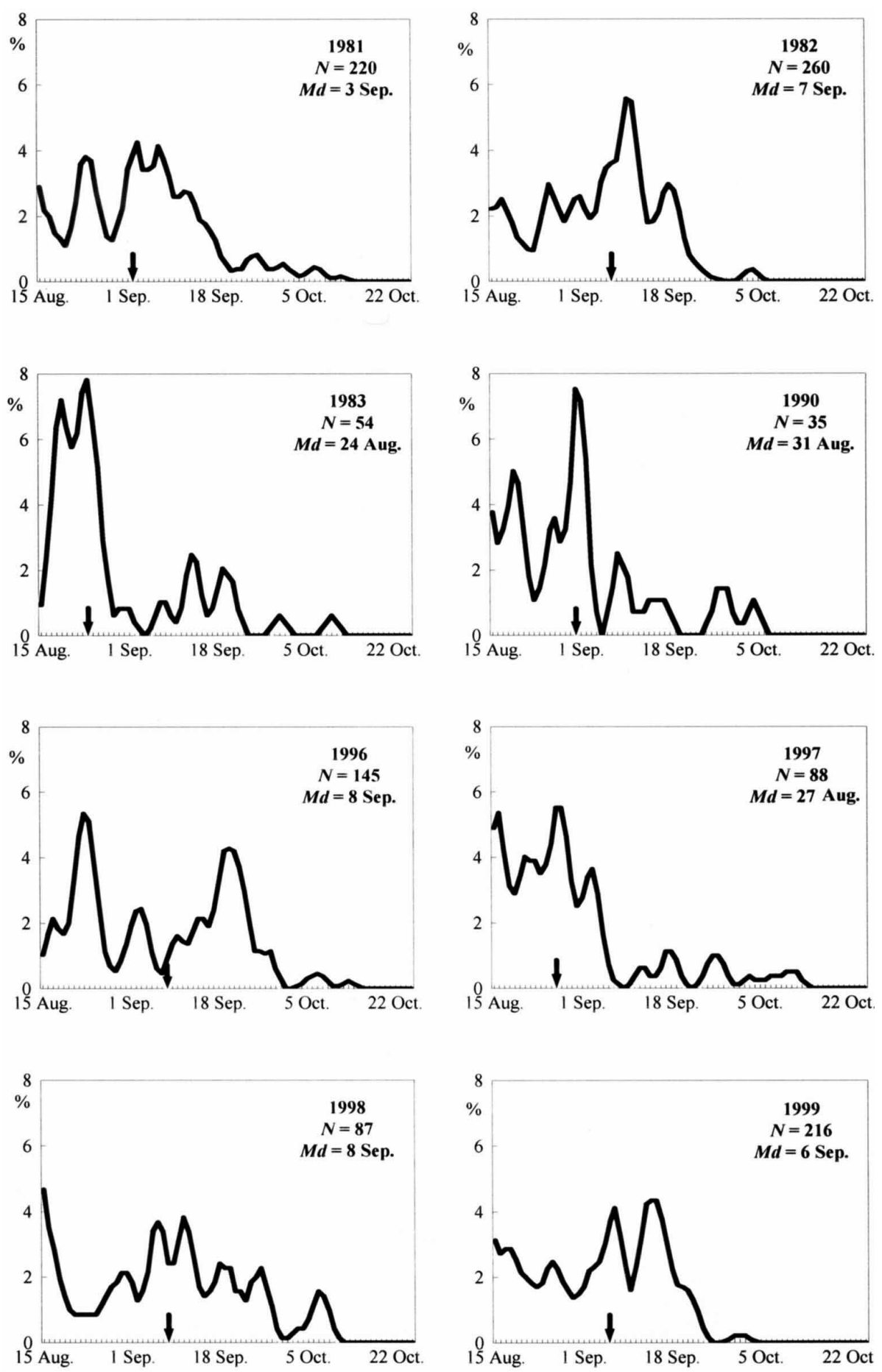
APPENDIX

Acrocephalus scirpaceus - Bukowo-Kopań
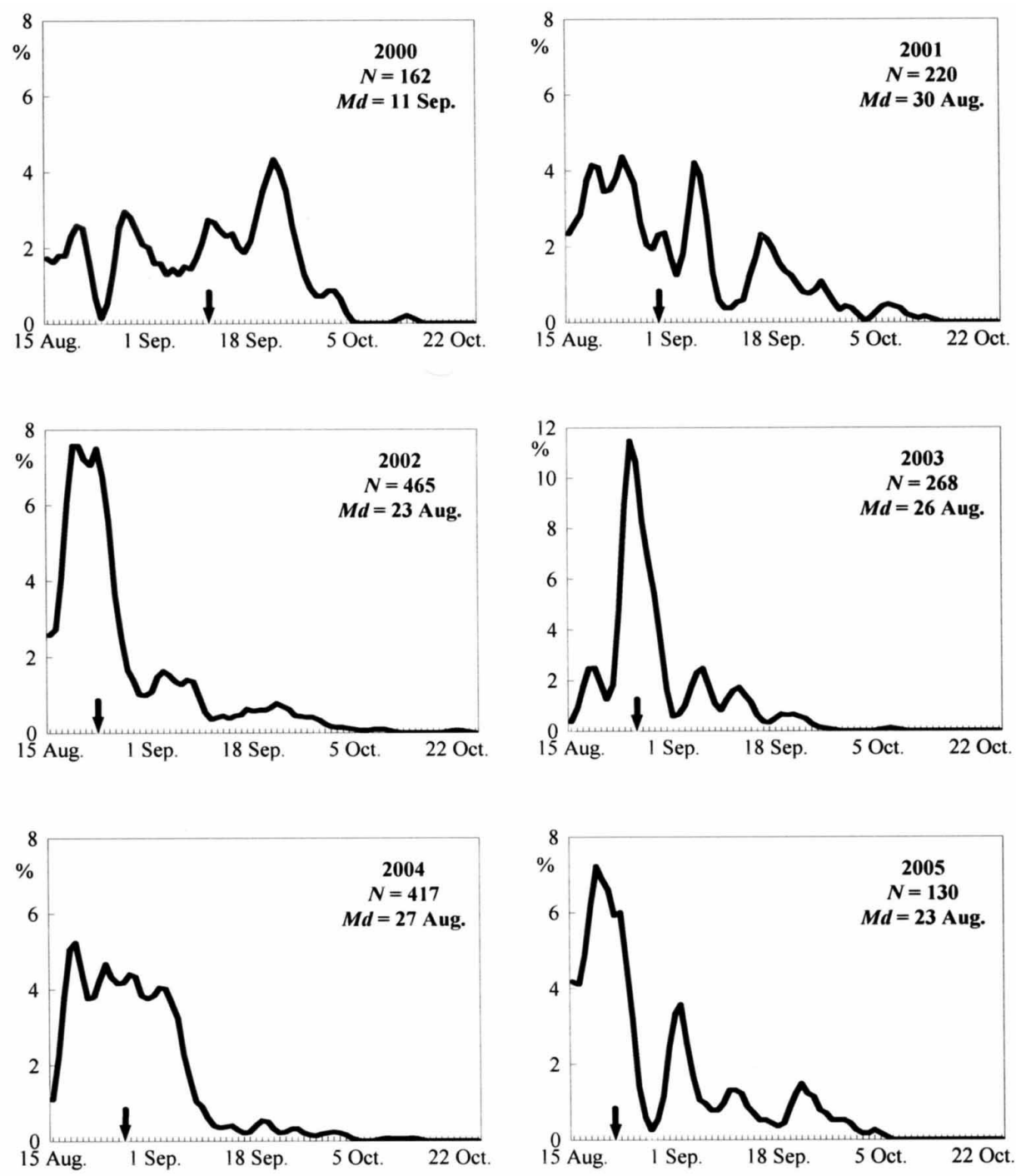

A. Seasonal migration dynamics of the Reed Warbler at Bukowo-Kopan within the $1^{\text {st }}$ standard period for the years with the number of caught birds $>30$. The median dates, indicated by arrows, are given only for the years when the catching season comprised the whole $1^{\text {st }}$ standard period. $N$-number of birds caught in the whole catching period, $M d$-median date. 
APPENDIX

Acrocephalus scirpaceus - Mierzeja Wiślana
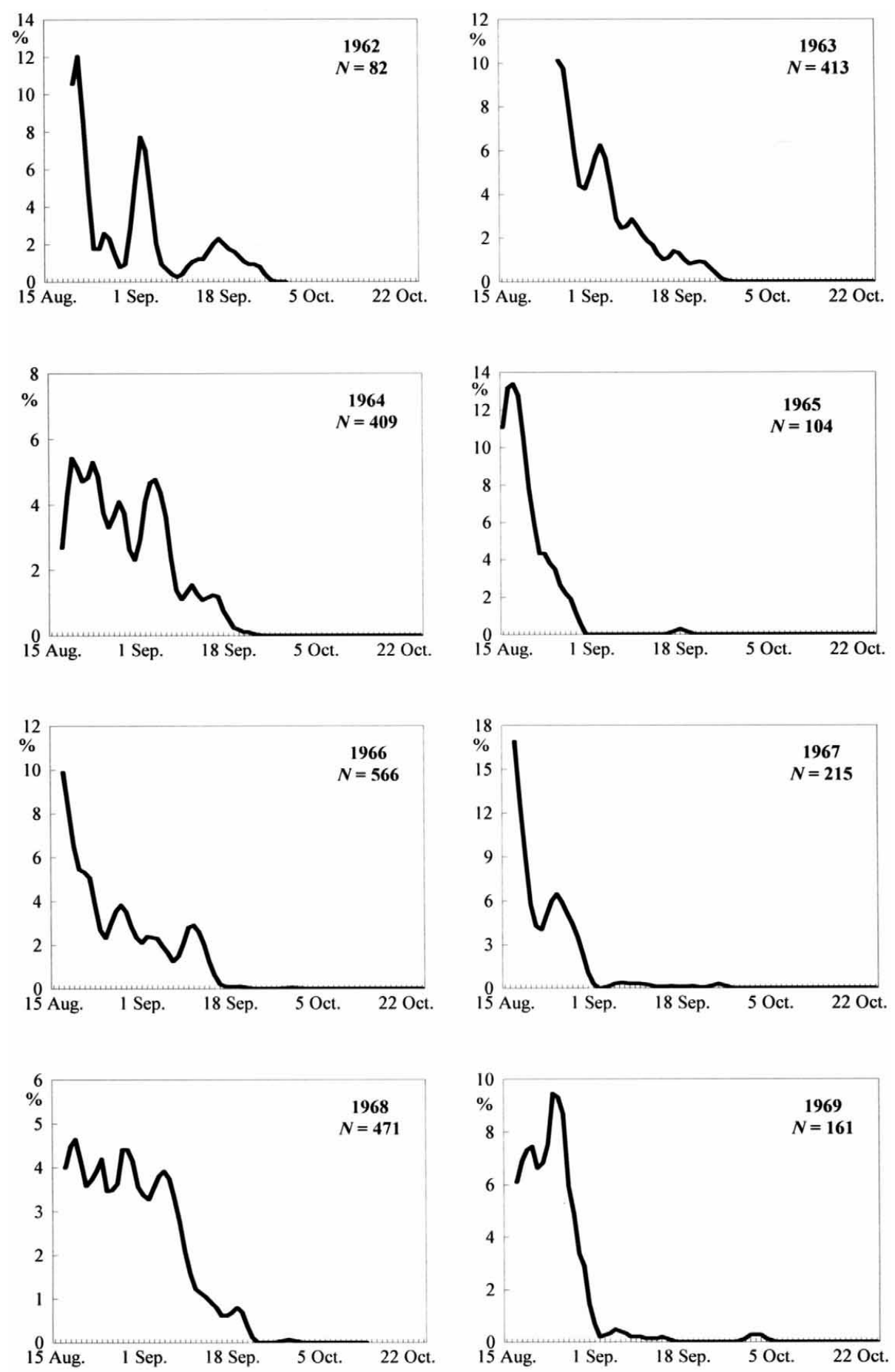
APPENDIX

Acrocephalus scirpaceus - Mierzeja Wiślana
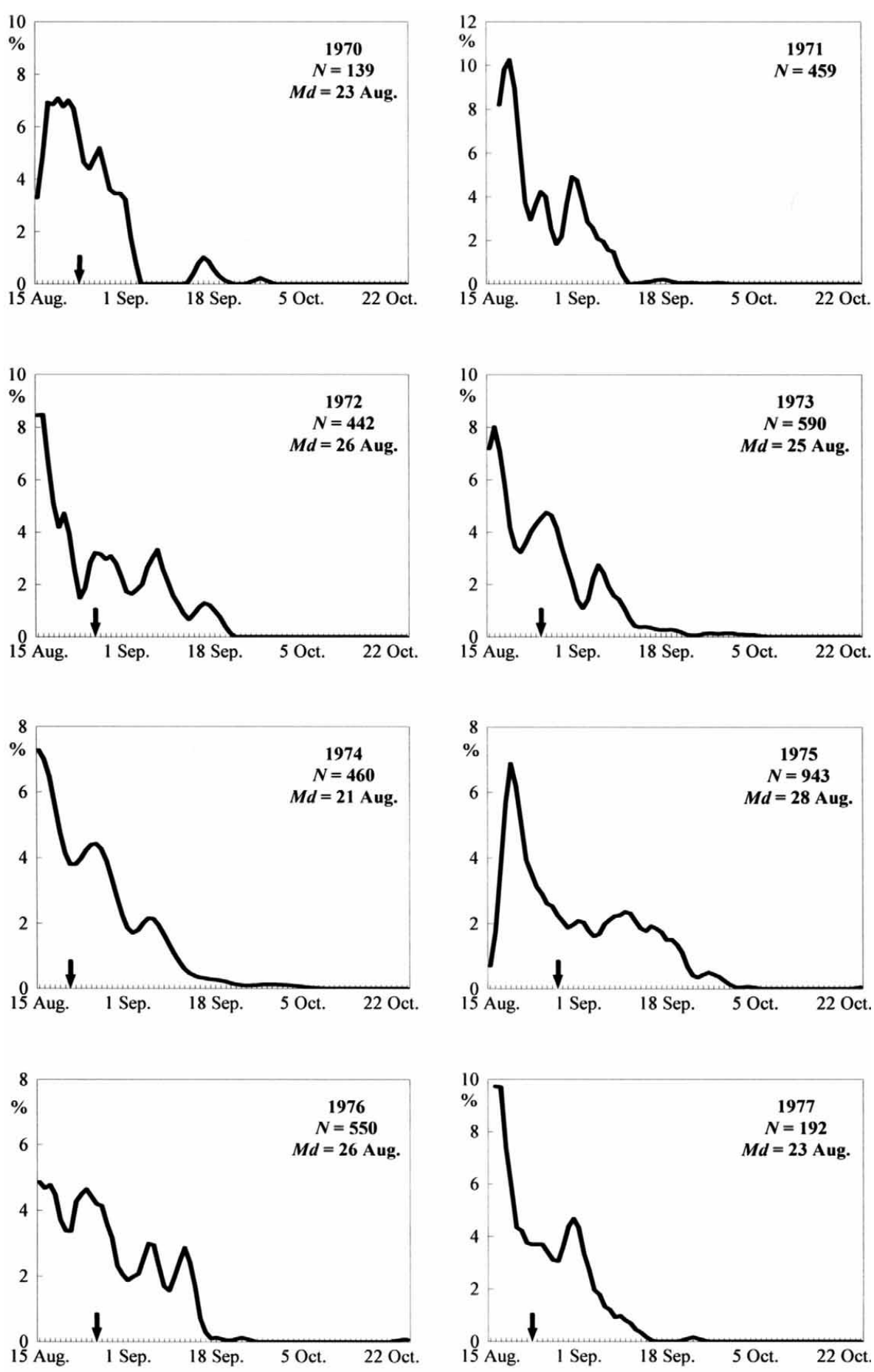
APPENDIX

Acrocephalus scirpaceus - Mierzeja Wiślana
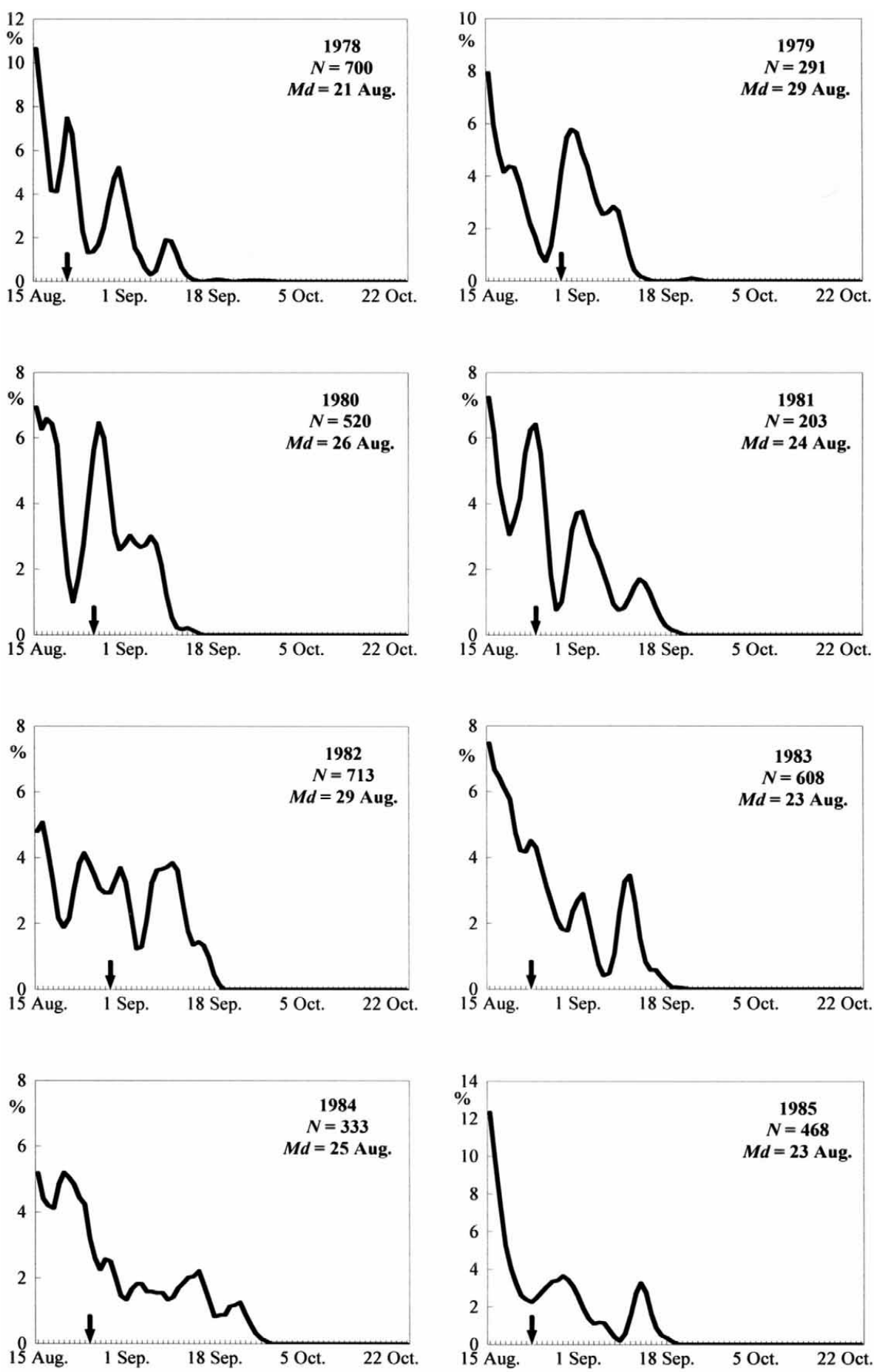
APPENDIX

Acrocephalus scirpaceus - Mierzeja Wiślana
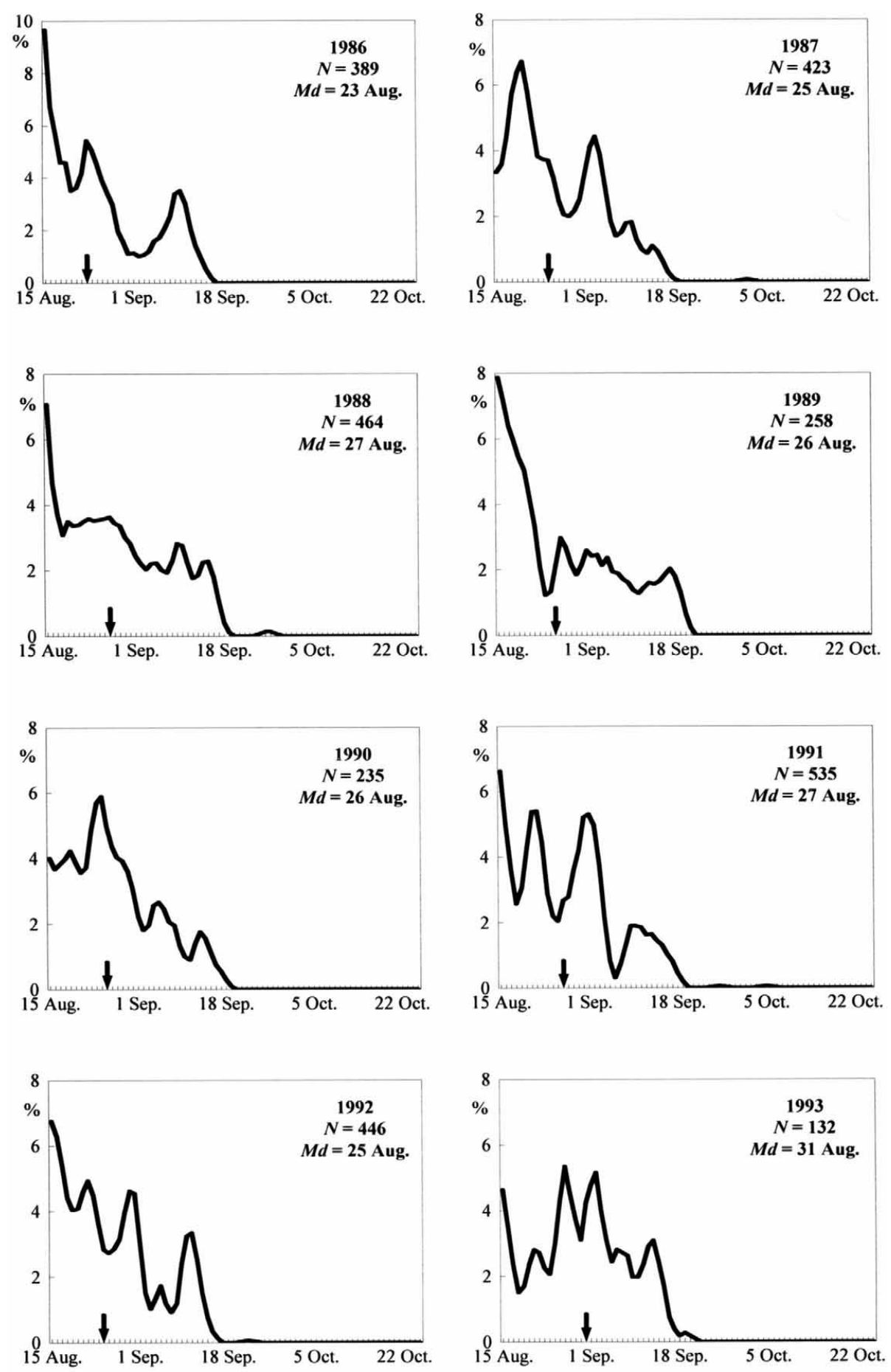
APPENDIX

Acrocephalus scirpaceus - Mierzeja Wiślana
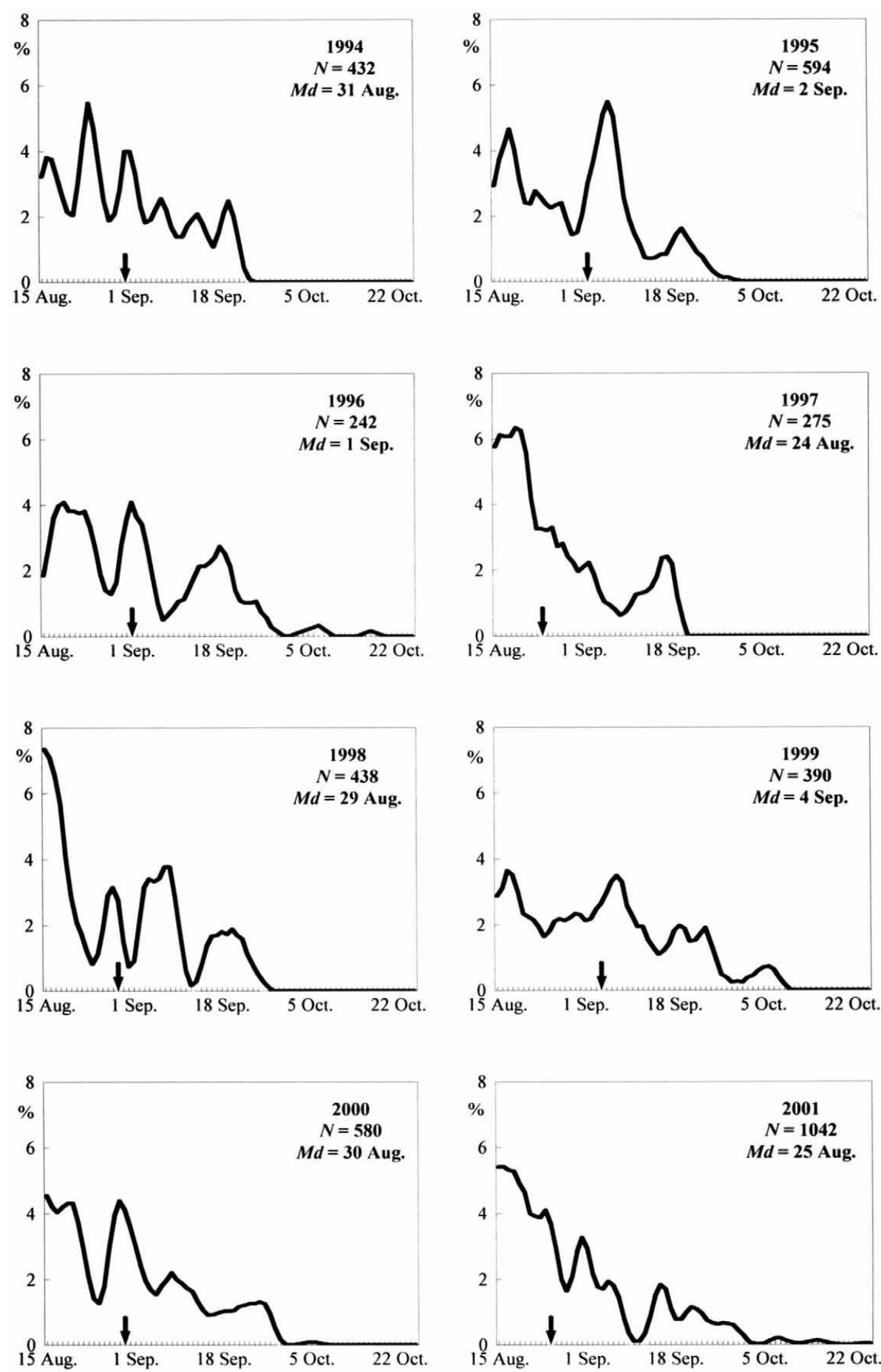
THE RING 31, 2 (2009)

43

APPENDIX

Acrocephalus scirpaceus - Mierzeja Wiślana
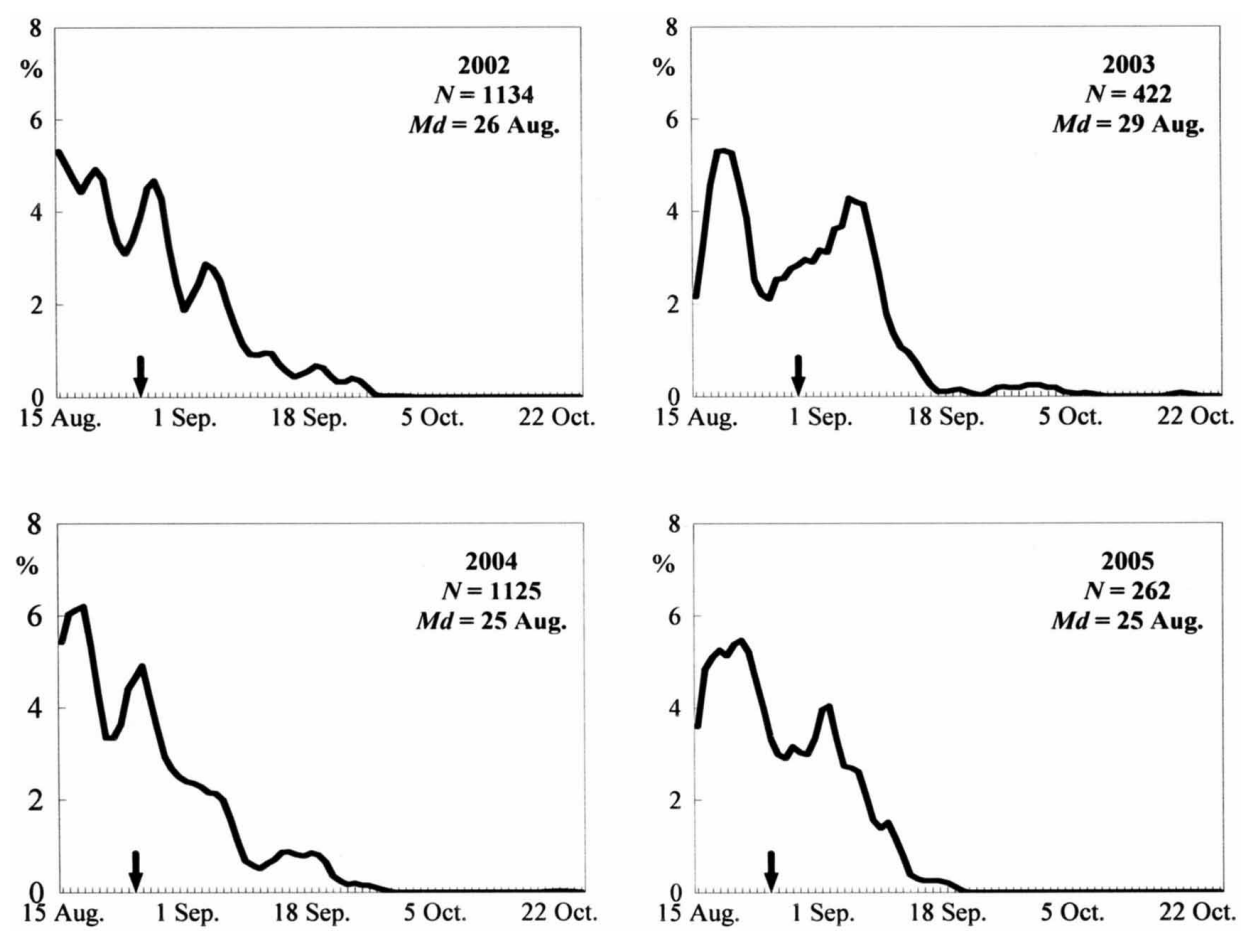

B. Seasonal migration dynamics of the Reed Warbler at Mierzeja Wiślana within the $1^{\text {st }}$ stanard period for the consecutive years. The median dates, indicated by arrows, are given only for the years when the catching season comprised the whole $1^{\text {st }}$ standard period. $N$-number of birds caught in the whole catching period, $M d$ - median date. 